\title{
Thermal Desalination of Produced Water-An Analysis of the Partitioning of Constituents into Product Streams and Its Implications for Beneficial Use Outside the O\&G Industry
}

\author{
Ganesh L. Ghurye ${ }^{1, *}$, Dhananjay Mishra ${ }^{2}$ and Luke Lucas ${ }^{2}$ \\ 1 ExxonMobil Upstream Research Company, Spring, TX 77389, USA \\ 2 Advisian, Houston, TX 77079, USA; dhananjay.mishra@advisian.com (D.M.); luke.lucas@advisian.com (L.L.) \\ * Correspondence: ganesh.l.ghurye@exxonmobil.com; Tel.: +1-832-624-9363
}

Citation: Ghurye, G.L.; Mishra, D.; Lucas, L. Thermal Desalination of Produced Water-An Analysis of the Partitioning of Constituents into Product Streams and Its Implications for Beneficial Use Outside the O\&G Industry. Water 2021, 13, 1068. https://doi.org/10.3390/w13081068

Academic Editor: Pei Xu

Received: 9 March 2021

Accepted: 7 April 2021

Published: 13 April 2021

Publisher's Note: MDPI stays neutral with regard to jurisdictional claims in published maps and institutional affiliations.

Copyright: (c) 2021 by the authors. Licensee MDPI, Basel, Switzerland. This article is an open access article distributed under the terms and conditions of the Creative Commons Attribution (CC BY) license (https:// creativecommons.org/licenses/by/ $4.0 /)$.

\begin{abstract}
To understand partitioning of produced water (PW) constituents using thermal desalination, PW from the Delaware Basin was desalinated using a crystallization process and modeled using OLI Systems, Inc. (OLI, Parsippany, NJ, USA) chemistry software. The incorporation of a pretreatment step, steam stripping, prior to desalination was predicted to be effective at removing hydrocarbons (across a range of volatilities). As expected, inorganics were almost completely retained in the residual brine which was confirmed by OLI. As evaporation progressed, sparingly soluble compounds such as gypsum and celestite precipitated first and overall solids production at this stage was low $(<1 \%$ of total solids). Further evaporation resulted in saturation of the residual brine with respect to $\mathrm{NaCl}$, which started to precipitate in bulk up to a practical desalination limit of approximately $68 \%$ by mass (approximately $80 \%$ by volume). Beyond this point, the residual brine and solids mixture became too viscous to be pumped. Gravimetrically determined total dissolved solids (TDS) for PW, distillate and residual brine was found to be much higher than prediction, potentially due to the presence of neutral species, unstripped gases and organic (likely hydrophilic) constituents. Although the distillate had low TDS, the presence of unknown constituents including organic compounds in the distillate will likely require polishing treatment to mitigate potential toxicity associated with such compounds or transformation products post-release if discharged to the environment. OLI predicted near-complete retention of acetate in the residual brine. In contrast, laboratory tests showed nearly $50 \%$ partitioning of acetate into the distillate. Although not modeled, propionate partitioning was even higher at $94 \%$. The inclusion of ammonia as an input species in OLI greatly improved the match between test data and model prediction. Additionally, it was hypothesized that acetic acid/acetate could have formed a volatile adduct with ammonia that increased its volatility and partitioning into the distillate. The findings of this study inform beneficial use by describing the chemical composition of desalination-derived distillate, brine and salt products. This study also identified alternative approaches, both treatment and non-treatment, for managing PW from unconventional operations.
\end{abstract}

Keywords: produced water treatment; thermal desalination; crystallization; partitioning; beneficial use; solids; salt; waste generation; resource recovery; bromine; iodine; lithium; OLI

\section{Introduction}

A recent increase in oil and gas activity in the Delaware Basin in south-eastern New Mexico (NM) is expected to generate large volumes of produced water (PW). Based on figures provided by the Oil Conservation Division (OCD) of the New Mexico Energy, Minerals and Natural Resources Department, Veil [1] reported that in 2017 approximately 880 million barrels of PW was generated in New Mexico. Approximately 50\% of the generated PW was managed by injection into salt water disposal (SWD) wells, 40\% was used for enhanced oil recovery and $10 \%$ was reused within the O\&G industry. ExxonMobil, through its subsidiary XTO, is one of the major operators in the Delaware Basin and has a goal of maximizing reuse of PW in on-going operations, which serves to limit the use 
of fresh water in its operations and reduce PW sent to disposal. To enable maximum reuse, XTO is building an extensive network of pipelines and storage ponds in its area of operations and uses service providers to treat raw PW to a specification suitable for reuse in on-going hydraulic fracturing operations (see Supplemental Information (SI) for typical reuse quality requirements). Briefly, raw PW is treated to reduce/remove oil and grease, total suspended solids (TSS) and iron with $\mathrm{pH}$ adjustment within a range of 6 to 8 SU (standard units). Additionally, and as needed, an oxidant (typically chlorine) is added to provide a high enough redox potential in the treated PW to control biological growth and reduce $\mathrm{H}_{2} \mathrm{~S}$ to non-detect levels. Treated $\mathrm{PW}$ is then stored in dedicated storage ponds and reused as/when necessary.

In addition to the above PW management practices, there has been an increased interest in using desalinated PW for beneficial purposes in the State of New Mexico; such beneficial uses envisage potential applications outside the O\&G industry. In 2018, the United States Environmental Protection Agency (US EPA) signed a memorandum of understanding with the State of New Mexico; its stated purpose was "to embark on a state and federal effort to clarify the existing regulatory and permitting frameworks related to the way PW can be re-used, recycled and renewed for purposes in New Mexico [2]." New Mexico is considered an arid state and receives just 15 inches of rainfall per year, and even though a recent study concluded that availability of desalinated PW will not meaningfully alter regional water scarcity [3], there still exists substantial support for initiatives to determine if beneficial use can augment the state's scarce water resources. Depending on the intended beneficial use, PW will have to be treated to an appropriate specification. For reuse in on-going operations, where treated PW does not enter the environment, minimal treatment as noted above is sufficient. However, for other beneficial uses such as irrigation or surface discharge, it is likely that PW will require desalination and post-desalination polishing treatment to meet a stricter specification.

Unconventional operations typically produce water in two phases. An initial high rate of water, termed flowback, is primarily composed of injected fracturing fluid returning to the surface. After this initial high rate which can last from a few days to weeks, water that returns to the surface is termed PW. Flowback and PW are typically not segregated, and PW storage facilities usually contain PW that is commingled with flowback water. Therefore, for purposes of this study, no distinction is drawn between these two types of water produced from unconventional wells.

Produced water contains a range of constituents, both organic and inorganic and these constituents may have their origin in un-transformed oil field chemicals used in drilling and fracturing, transformation products of these oil field chemicals or naturally originate from the formation itself. Of the inorganic constituents, the predominant ions found in most unconventional PWs are sodium $(\mathrm{Na})$ and chloride $(\mathrm{Cl})$ with lower concentrations of other major ions—cations such as calcium (Ca), magnesium (Mg), iron (Fe), manganese $(\mathrm{Mn})$, aluminum $(\mathrm{Al})$ and potassium $(\mathrm{K})$ and anions such as sulfate $\left(\mathrm{SO}_{4}{ }^{2-}\right)$, fluoride $(\mathrm{F})$, bicarbonate $\left(\mathrm{HCO}_{3}{ }^{-}\right)$, and phosphate $\left(\mathrm{PO}_{4}{ }^{3-}\right)$ commonly present in ground and surface waters. Additionally, PWs have been reported to contain ions that are not commonly found in ground/surface waters or are present at elevated concentrations not typical of ground/surface waters. These include cations such as barium (Ba), lead (Pb), lithium ( $\mathrm{Li})$, radium ( $\mathrm{Ra})$, strontium (Sr) and zinc $(\mathrm{Zn})$, and anions such as bromide (Br) and iodide (I). Other inorganics found in PW include neutral compounds such as silica $\left(\mathrm{SiO}_{2}\right)$ and boron $\left(\mathrm{B}(\mathrm{OH})_{3}\right)$ and dissolved gases such as ammonia $\left(\mathrm{NH}_{3}\right)$ and hydrogen sulfide $\left(\mathrm{H}_{2} \mathrm{~S}\right)$ [4-8].

A wide range of volatile (VOC), semi-volatile (sVOC) and non-volatile (nVOC) organic compounds have been reported in unconventional flowback and/or PW. Among oilfield chemicals, the presence of surfactants, alcohols and biocides have been reported in literature [6,9-12]. The presence of aliphatic acids, aldehydes, ketones, some alcohols and halogenated organic compounds is generally attributed to transformation products $[6,13]$. Other organic compounds reported to be found in unconventional PWs include benzene, 
toluene, ethylbenzene and xylene (BTEX), diesel range organics (DRO), and parent and alkyl-substituted aromatics [7,9-12,14,15].

Unconventional PWs are often associated with evaporite salt deposits, which are preferentially enriched in highly soluble ions such as $\mathrm{Br}$, I and Li when compared with their concentration in seawater. Consequently, formation water in contact with these evaporite deposits also show such preferential enrichment, which can be a benefit as well as a risk. If extracted from $\mathrm{PW}$ (raw or post-desalination residual brine), $\mathrm{Br}, \mathrm{I}$ and $\mathrm{Li}$ have commercial value. However, in the presence of oxidants such as chlorine, $\mathrm{Br}$ and I form halogenated acids ( $\mathrm{HOBr}$ and $\mathrm{HIBr}$ ), which can react with organics in $\mathrm{PW}$ to form brominated and iodinated organic compounds [13,16-20]. These $\mathrm{Br}$ - and I-containing organics may partition into desalination products such as distillate and/or contaminate salts intended for beneficial use. If present in beneficially used distillate and/or salt, $\mathrm{Br}$ and I can also be incorporated into organic compounds post-release into the environment (such as discharge of distillate to a surface stream or use of salt for road de-icing). These halogenated organics are stated to be two to three orders of magnitude more cytotoxic and genotoxic than their chlorinated analogs [21-23] with reported adverse health impacts observed at the sub $\mu \mathrm{g} / \mathrm{L}$ levels. While the generation of halogenated organics has generally been attributed to abiotic reactions, Almaraz, et al. [14] recently reported the formation of substantial concentrations of trihalomethanes (THMs, 4000 microgram per litre $(\mu \mathrm{g} / \mathrm{L})$ ) during biological treatment of PW from the Denver-Julesburg (DJ) basin in Colorado. PWs from this basin, however, are much lower in total dissolved solids (TDS, 15,000 milligram per litre (mg/L)) compared to the Delaware Basin in NM (>200,000 mg/L) or the Marcellus Basin in PA (>300,000 mg/L) [24]. It is not known if the microbial community responsible for the biotic formation of THMs in the DJ basin can survive in a much higher TDS environment characteristic of PWs in the Delaware Basin and generate $\mathrm{Br}$ - and I-organic compounds. It should also be noted that halogenated organic compounds are generally hydrophobic and, therefore, should be amenable to efficient removal from either raw or desalinated PW using available treatment technologies such as air/steam stripping and granular activated carbon (GAC) adsorption.

For the purposes of this study, the authors reviewed currently available desalination technologies capable treating PWs with TDS in the range of 200,000 to 250,000 mg/L. While several technologies such as membrane distillation (MD) are being developed for high-TDS PW treatment, currently only thermal technologies such as evaporation and crystallization are able to treat such high TDS waters at scale. For most Delaware PWs, the TDS is already too high for treatment using an evaporator; typically, the reject brine from an evaporator has a TDS of approximately $220,000 \mathrm{mg} / \mathrm{L}$. Therefore, crystallization was selected as the preferred desalination technology, and modelling and laboratory studies were performed to understand partitioning behaviour and mass balance distributions of PW constituents in distillate, brine and salt streams resulting from this process.

A conceptual illustration of constituents partitioning into product and waste streams upon thermal desalination and potential follow-on polishing steps to remove impurities is shown in Figure 1. PW typically undergoes primary treatment for the removal of oil and grease, suspended solids (TSS) and iron (Fe). Additionally, dissolved gases such as hydrogen sulfide $\left(\mathrm{H}_{2} \mathrm{~S}\right)$ can be oxidized via the addition of an oxidant such as chlorine, which also serves to increase the redox potential of treated PW for bacterial control. Usually, this minimal treatment, often termed "floc and drop" in industry parlance is sufficient for its reuse in on-going operations. Depending on PW quality, additional softening treatment may be required to remove easily scaled/precipitated or sparingly soluble ions such as barium (Ba) and strontium ( $\mathrm{Sr}$ ) via the addition of a sulfate source (typically, sodium sulfate $\left(\mathrm{Na}_{2} \mathrm{SO}_{4}\right)$ ). Radium ( $\left.\mathrm{Ra}\right)$, if present, is readily co-precipitated with $\mathrm{Ba}$. Concerns related to corrosion and/or carbonate scaling in the crystallizer may also trigger the use of a steam stripping step (not shown in Figure 1) where the $\mathrm{pH}$ of $\mathrm{PW}$ is typically lowered to $\sim 4.0$ followed by the addition of steam. A small amount (typically $<1 \%$ ) of PW does evaporate along with volatile organics. Depending on $\mathrm{pH}$, dissolved gases such as $\mathrm{H}_{2} \mathrm{~S}$, 
$\mathrm{NH}_{3}, \mathrm{CO}_{2}$ (alkalinity) may also be removed. After readjusting the $\mathrm{pH}$ to $\sim 6.5$, the pretreated $\mathrm{PW}$ is ready to be sent to a crystallizer. The illustration in Figure 1 shows a residual brine, which is usually unavoidable if a pure sodium chloride $(\mathrm{NaCl})$ salt is desired. However, a crystallizer can also be run in a zero-liquid discharge mode, where almost all of the water is evaporated to generate a mixed salt, which has no commercial value.

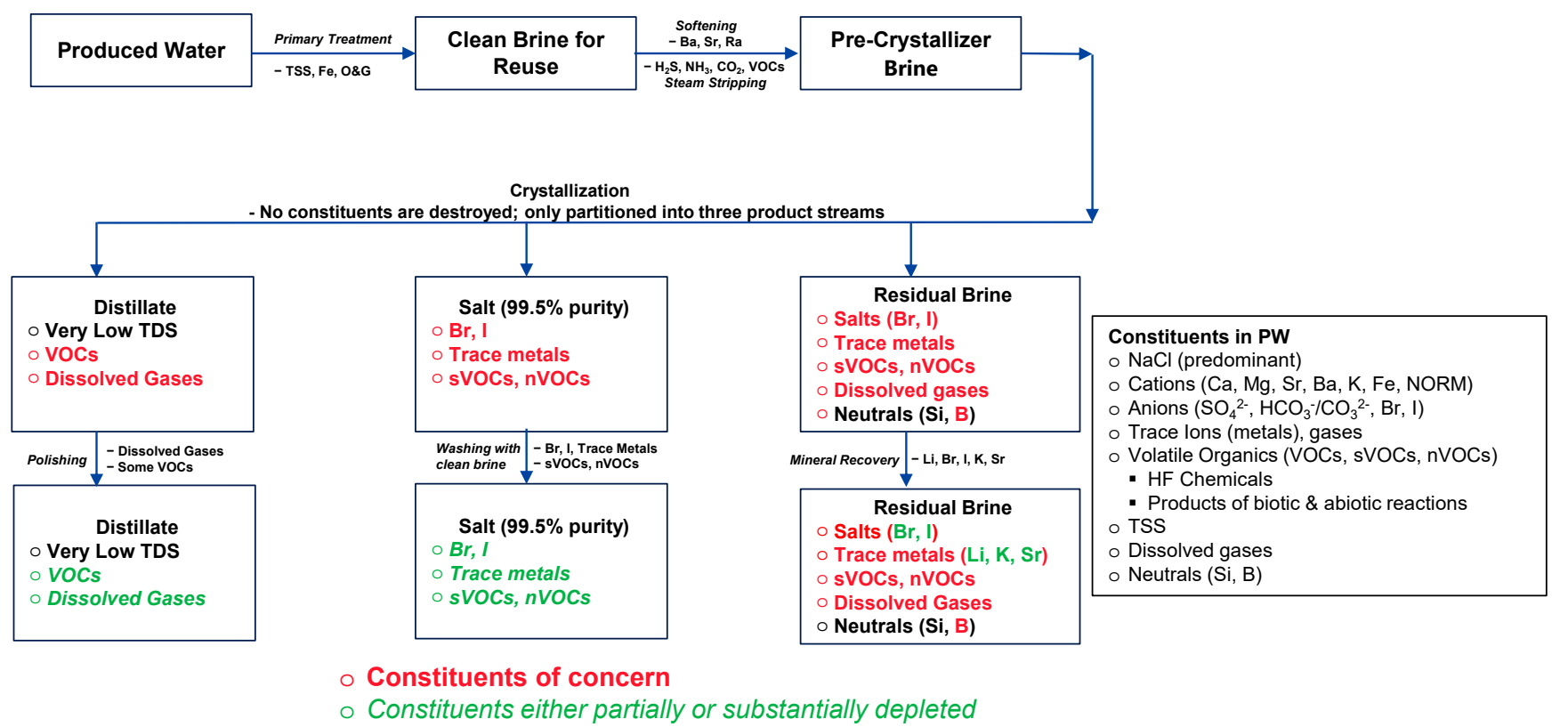

Figure 1. Conceptual illustration of the partitioning behaviour of PW constituents following thermal desalination (crystallization).

Typically, the desalinated PW or the distillate has low TDS comprising trace concentrations of inorganic ions, organic compounds and potentially any unstripped gas(es). Organics present in the distillate can be due to unstripped VOCs and potentially carryover of entrained liquid (mist) along with the water vapor. Although mist eliminators are utilized to capture entrained liquid, these are not always 100\% efficient and some carryover of entrained liquid into the distillate usually occurs. Such a carryover can result in an increase in TDS of the distillate.

In summary, unconventional oil and gas development in the Delaware Basin in New Mexico (NM) is expected to generate large quantities of PW in future decades. Currently, PW is managed by either injection into SWD wells or treatment followed by reuse in on-going operations. However, should either option face constraints, beneficial use of desalinated $\mathrm{PW}$ is being proposed as a potential alternative for managing excess $\mathrm{PW}$. Additional drivers for beneficial use include alleviating regional water scarcity through surface discharge of desalinated water and/or using it to meet the local freshwater demand, thereby conserving fresh water resources. PW contains various inorganic and organic constituents that can potentially have an adverse impact, if released untreated into the environment. To develop a better understanding of the risks that could impede beneficial use, two foundational studies are required: (1) characterization of constituents in untreated PW and (2) an understanding of how / where these constituents partition into product (i.e., distillate and recovered salts) and waste streams (i.e., residual brine) post-desalination. To date, there have been numerous studies focused on understanding the composition of untreated PW. However, the partitioning behavior of PW constituents upon desalination has not been systematically characterized. The objective of this study was to address this critical data gap.

Specific tasks associated with the study of the partitioning behavior of PW constituents during crystallization are noted below. 
1. Develop a representative Delaware Basin PW quality for OLI simulation;

2. Develop a conceptual crystallization process using OLI to provide an insight into the theoretical partitioning behavior and mass balance distribution of critical PW constituents;

3. Perform bench-scale laboratory testing to verify predicted partitioning behavior of various major and trace ions, identifiable organics, characterize solids formation, evaluate potential for extraction of valuable elements ( $\mathrm{Li}, \mathrm{Br}$, and I), and validate the OLI model.

Note that while this paper describes the partitioning behavior of PW constituents upon crystallization, the methodology/approach described in this paper can be adapted to other desalination technologies and differing PW qualities from other unconventional basins as well.

\section{Materials and Methods}

\subsection{Produced Water Quality Used in Laboratory and OLI Modeling}

The PW used in this study was obtained from on-going recycling operations in the Delaware Basin where commingled PW from multiple wells and formations was pretreated via a combination of micro- and ultra-filtration units. The commingled PW was similar to the PW quality from the Delaware Mountain group (see Table 1).

Filtration pretreatment was used to remove TSS, oil and grease and iron (after oxidation with chlorine). Post filtration, a total of six gallons each of micro- and ultra-filtered PW was sent to Intertek in Houston, TX, USA (samples were maintained over ice for the duration of transport). Upon receipt, the PW was combined into a single 12-gal sample used to conduct the laboratory tests.

As seen in Table 1, gravimetric TDS was 14\% higher than lab-calculated TDS based on ionic composition. Potential reasons for this discrepancy may include analytical errors (due to high dilution of PW required prior to inorganic analyses), inorganics (including gases) that were not analyzed in this study as well as organics present in PW such as corrosion inhibitors, demulsifiers and those of geogenic origin. Analytical errors were minimized by analyzing samples in triplicate; however, based on comments provided by the analytical laboratory, an error of approximately $\pm 15 \%$ for the high TDS samples was possible. With regard to VOCs, it should be noted that prior to transport, $\mathrm{PW}$ was exposed to atmosphere at various times during storage and pretreatment as described above. During transport, sample containers were sealed to guard against leaks but no attempt was made to make the containers completely air-tight during shipment. Therefore, the concentration of VOCs in the originally-generated PW may be expected to have substantially depleted by the time PW samples were subjected to laboratory analysis.

Concentrations of aluminum, cobalt, lead, fluoride, and silica used in OLI modeling were based on average concentrations of these constituents in the Delaware Mountain Group (see Table 1) and were not separately analyzed (partitioning behavior tracked based only on OLI model predictions). 
Table 1. Representative PW water quality used in this study.

\begin{tabular}{|c|c|c|c|c|c|}
\hline \multirow{2}{*}{$\begin{array}{c}\text { Water Quality } \\
\text { Parameter }\end{array}$} & \multicolumn{3}{|c|}{ Delaware Mountain Group } & \multirow{2}{*}{$\begin{array}{c}\text { Study PW } \\
\text { ppm (mass) }\end{array}$} & \multirow{2}{*}{$\begin{array}{c}\text { Study PW } \\
\text { mg/L }\end{array}$} \\
\hline & Avg. (mg/L) & Min & Max & & \\
\hline \multicolumn{6}{|c|}{ General } \\
\hline $\mathrm{pH}(\mathrm{su})$ & 6.4 & 5.0 & 7.4 & & \\
\hline TDS (Gravimetric-Lab) & 245,691 & 38,903 & 355,107 & 253,678 & 295,458 \\
\hline TDS (Calculated-Lab) & & & & 222,898 & 259,609 \\
\hline Temperature, Field & & & $70^{\circ} \mathrm{F}$ & & \\
\hline Temperature, Lab & & & $86.5^{\circ} \mathrm{F}$ & & \\
\hline \multicolumn{6}{|c|}{ Cations } \\
\hline $\mathrm{Ca}^{2+}$ & 24,304 & 341 & 31,656 & 20,946 & 24,772 \\
\hline $\mathrm{Mg}^{2+}$ & 2991 & 70 & 4137 & 3238 & 3829 \\
\hline $\mathrm{Fe}^{2+}$ & 33 & 0.3 & 80 & 0.1 & 0.1 \\
\hline $\mathrm{K}^{+}$ & 1715 & 209 & 2529 & 1538 & 1819 \\
\hline $\mathrm{Na}^{+}$ & 65,280 & 13,307 & 83,690 & 60,427 & 71,465 \\
\hline $\mathrm{Ba}^{2+}$ & 3.9 & 0.3 & 11 & 2.6 & 3.1 \\
\hline $\mathrm{Sr}^{2+}$ & 1101 & 92 & 1903 & 1130 & 1336 \\
\hline $\mathrm{Li}^{+}$ & 36 & 12 & 53 & 13 & 16 \\
\hline $\mathrm{Mn}^{2+}$ & 6.9 & 0.2 & 17 & 4.9 & 5.8 \\
\hline $\mathrm{Zn}^{2+}$ & 0.5 & ND & 9.3 & 0.1 & 0.1 \\
\hline $\mathrm{Al}^{3+}$ & 0.5 & ND & 3.7 & NT & NT \\
\hline $\mathrm{Co}^{2+}$ & 0.1 & ND & 0.3 & NT & NT \\
\hline $\mathrm{Pb}^{2+}$ & 0.2 & ND & 0.5 & NT & NT \\
\hline \multicolumn{6}{|c|}{ Anions } \\
\hline $\mathrm{Cl}^{-}$ & 152,589 & 22,200 & 253,125 & 133,648 & 158,062 \\
\hline $\mathrm{Br}^{-}$ & 1329 & 41 & 2467 & 1397 & 1652 \\
\hline $\mathrm{SO}_{4}{ }^{2-}$ & 201 & 41 & 664 & 409 & 484 \\
\hline $\mathrm{HCO}_{3}{ }^{-}$ & 121 & 12 & 805 & 16 & 19 \\
\hline $\mathrm{F}^{-}$ & 8.2 & 0.9 & 37 & NT & NT \\
\hline $\mathrm{I}^{-}$ & NT & & & 57 & 67 \\
\hline \multicolumn{6}{|c|}{ Neutrals (uncharged inorganic constituents) } \\
\hline $\mathrm{Si}\left(\right.$ as $\left.\mathrm{SiO}_{2}\right)$ & 9.1 & 4.2 & 45 & NT & NT \\
\hline $\mathrm{B}\left(\right.$ as $\left.\mathrm{B}(\mathrm{OH})_{3}\right)$ & 143 & 11 & 377 & 141 & 167 \\
\hline \multicolumn{6}{|c|}{ Organics } \\
\hline BTEX & NT & & & $<10$ & \\
\hline Acetic Acid & NT & & & 44.6 & \\
\hline Propionic Acid & NT & & & 2.1 & \\
\hline
\end{tabular}

Note 1: NT—Not tested; ND—Not detected. Note 2: The Delaware Mountain Group data shown is the average value for the listed parameters from 43 wells.

\subsection{Resource Recovery-Lithium (Li), Bromine (Br) and Iodine (I) Extraction}

As it pertains to beneficial use of PW or products derived from PW, the concentration of inorganic ions such as bromide, iodide and lithium assume significant importance for the following reasons. Lithium is of commercial value and hence there is increased interest in extracting this element from PWs. Bromine and iodine are also valuable chemicals used in a variety of industries. It is generally accepted that the source of these ions in PW is salt present in oil and gas bearing formations; these salts being derived from the evaporation of ancient sea water. What is not generally known is if these elements have the same ratio of $\mathrm{Cl}: \mathrm{Li}, \mathrm{Cl}: \mathrm{Br}$ and $\mathrm{Cl}: \mathrm{I}$ as that in seawater or if they are depleted or preferentially enriched compared with seawater concentrations. If preferentially enriched, these elements offer an attractive target for resource extraction. However, if left in desalination products intended for beneficial use, $\mathrm{Br}$ and I have the potential negative environmental ramifications discussed earlier. Therefore, if economically feasible, extraction from PW offers a win-win situation wherein a valuable resource can be recovered and the same time potential 
toxicity associated with Br- and I-organic compounds in desalination products can be greatly reduced.

\subsection{Laboratory Crystallizer Setup and Operation}

\subsubsection{Steam Stripper}

Pretreated PW was first stripped of dissolved gases using steam stripping to alleviate scaling and corrosion concerns. A bench-top atmospheric evaporator (Figure 2a), which included an evaporation flask, a heating mantle, a vapor condenser and a condensate receiver was used to approximate the steam stripping step. Its purpose was to drive off $\mathrm{H}_{2} \mathrm{~S}, \mathrm{CO}_{2}$, and $\mathrm{O}_{2}$ without vaporizing significant amounts of water. Produced water was first acidified to $\mathrm{pH} 4.0$ using sulfuric acid and fed into the evaporation flask and heated to its bubble point. The vapor generated from the flask was condensed and collected. Approximately 1\% (by volume) of the PW was vaporized during this step and captured. This is equivalent to a typical amount of water lost during full-scale steam stripping. The remaining PW was then cooled and prepared for further testing by raising the $\mathrm{pH}$ to 6.5 using sodium hydroxide. An additional benefit of steam stripping is that it has the potential to greatly reduce VOC concentrations in the product streams, especially in the distillate.
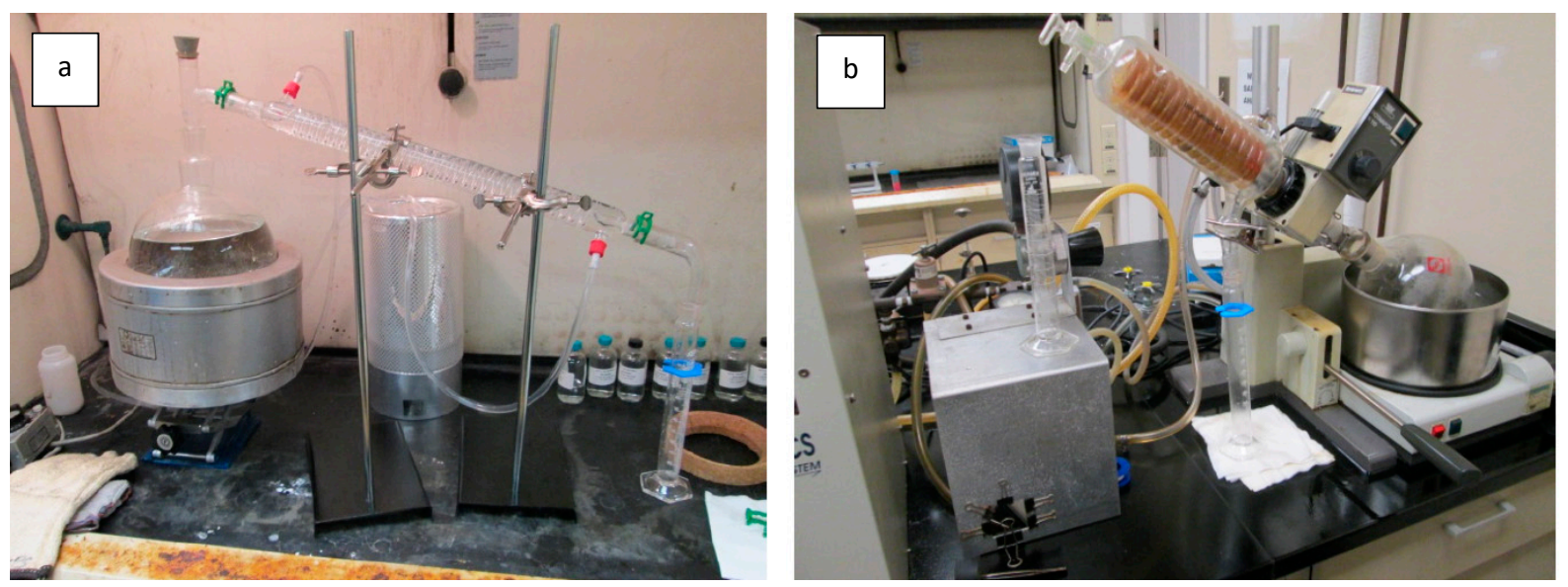

Figure 2. Pretreatment equipment used to simulate steam stripping (a), laboratory rotary evaporator used to simulate crystallization process (b).

\subsubsection{Crystallization}

A rotary evaporator (rotovap), as shown in Figure $2 b$, was used to simulate desalination using a vacuum crystallizer. The concentrated slurry (i.e., residual brine and salts) formed during evaporation was kept fluidized by the rotating action of the rotovap to represent pumped brine recirculation in a full-scale forced circulation crystallizer unit. This fluidization helped minimize solids settling in the rotovap and solids overheating in the bottom portion of the glassware.

\subsubsection{Sampling Schedule and Testing Method for Bench Tests}

Eight separate evaporation tests were performed, each at a specific "cut", as defined by the volume of distillate that was collected as a percentage of the starting pre-treated PW volume in the rotovap. Individual distillate and brine samples were thus collected for analysis at $10 \%, 20 \%, 30 \%, 40 \%, 50 \%, 60 \%, 70 \%$, and $80 \%$ by volume. Organic compounds analyzed in the laboratory included BTEX and five organic acids. Distillate and residual brine analysis was done in triplicate and included:

- $\quad \mathrm{pH}$, density, conductivity, calculated and gravimetric TDS, hardness, ionic balance.

- Inductively coupled plasma (ICP) spectroscopy cations analysis, including $\mathrm{Na}^{+}, \mathrm{Ca}^{2+}$, $\mathrm{Mg}^{2+}, \mathrm{Ba}^{2+}, \mathrm{Sr}^{2+}, \mathrm{Fe}^{2+}, \mathrm{K}^{+}, \mathrm{Li}^{+}, \mathrm{B}^{3+}, \mathrm{Mn}^{2+}$, and $\mathrm{Zn}^{2+}$. 
- $\quad$ Ion chromatograph (IC) anions analysis, including $\mathrm{Cl}^{-}, \mathrm{SO}_{4}{ }^{2-}, \mathrm{HCO}_{3}{ }^{-}, \mathrm{CO}_{3}{ }^{2-}, \mathrm{OH}^{-}$, $\mathrm{F}^{-}, \mathrm{Br}^{-}$, and $\mathrm{I}^{-}$.

- Ion chromatograph (IC) organic acid analysis, including formate, acetate, propionate, butyrate, and glycolate.

- Gas chromatograph (GC) equipped with a flame ionization detector (FID) for BTEX analysis.

A list of analytical methods used in this study is provided in the Supplementary Materials Section.

Solids samples were collected from the $30 \%, 60 \%$ and $80 \%$ evaporation tests and analyzed as noted below. Given that wetted solids were analyzed, the results were expected to also show those ions that were present in the moisture content/brine but not present in the salt/solid phase. Therefore, these results provide an insight into the co-contaminants that can be present in the salt and additional treatment that may be required to meet a given reuse specification.

- X-ray powder diffraction (XRD) analysis of residual inorganic solids.

- X-ray fluorescence (XRF) chemical analysis of recovered solid.

- Dissolution and ICP spectroscopy cations analysis of recovered solid, including $\mathrm{Ca}^{2+}$, $\mathrm{Mg}^{2+}, \mathrm{K}^{+}, \mathrm{Li}^{+}, \mathrm{Na}^{+}, \mathrm{B}^{3+}, \mathrm{P}^{5+}, \mathrm{Al}^{3+}, \mathrm{Si}^{4+}, \mathrm{Mn}^{2+}, \mathrm{Fe}^{2+}, \mathrm{Ni}^{2+}, \mathrm{Cu}^{2+}, \mathrm{Zn}^{2+}, \mathrm{Sr}^{2+}, \mathrm{Ba}^{2+}, \mathrm{Pb}^{2+}$, $\mathrm{Cd}^{2+}, \mathrm{Cr}^{+}$.

- Ion chromatograph (IC) anions analysis of recovered solids, including $\mathrm{F}^{-}, \mathrm{Cl}^{-}, \mathrm{Br}^{-}$, $\mathrm{I}^{-}, \mathrm{NO}_{3}, \mathrm{NO}_{2}{ }^{-}, \mathrm{SO}_{4}=\mathrm{PO}_{4}{ }^{3-}$.

Dissolution of wet solid samples was undertaken by adding $2 \mathrm{~g}$ of solid subsamples in $18 \mathrm{~g}$ of de-ionized water followed by filtering prior to analysis. It was noted by the laboratory that no residual solids remained on the filter prior to performing this testing.

\subsection{Desktop OLI Simulation}

\subsubsection{Simulation Approach}

The OLI model [25] block flow diagram (BFD) used in this study is shown in Figure 3 (additional details are presented in the Supplementary Materials Section). Crystallizer operation was simulated for a PW flow rate of 500,000 bbl/d. The BFD includes steam stripping using saturated steam (approximately $1 \%$ recovered in stripper overhead). Steam stripping was expected to remove bicarbonate (previously converted to $\mathrm{CO}_{2}$ via acid addition), VOCs, oxygen, and $\mathrm{H}_{2} \mathrm{~S}$, which are typically recovered in the stripper vent.

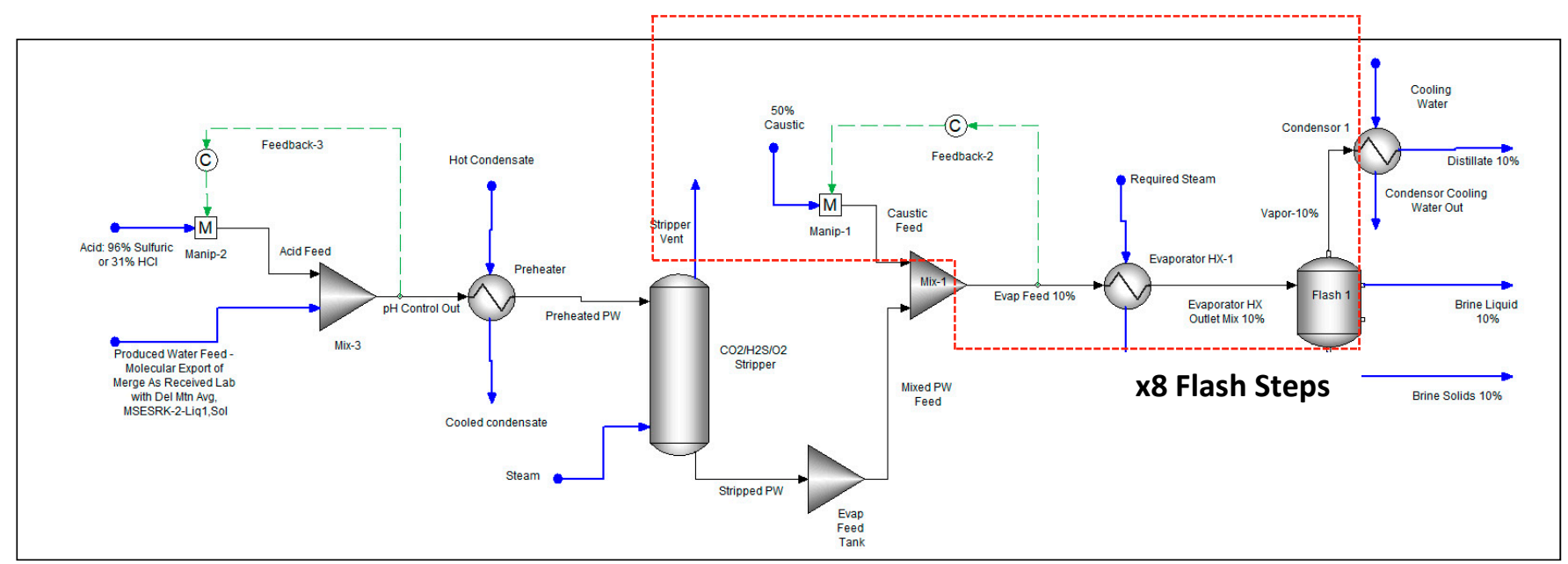

Figure 3. OLI simulation flowsheet for the process of the desalination of PW (flow rate $=500,000 \mathrm{bbl} / \mathrm{d} \mathrm{PW}$ ).

Following the steam stripper, $\mathrm{pH}$ of the stripped $\mathrm{PW}$ was adjusted to approximately 6.5 by adding $50 \%$ caustic soda to minimize corrosion in the crystallizer. $\mathrm{pH}$-adjusted $\mathrm{PW}$ was then heated to boiling in the multi-stage flash evaporation units where the amount of 
heat in in each stage was controlled to produce the required amount of distillate. Each stage of the multi-stage flash evaporation units produced a condensed distillate, residual brine and solid stream. The concentration and flow rate of input constituents in each stream were calculated by OLI and shown in the results of the simulation as a detailed report. The process model was designed to simulate multi-stage thermal desalination process with incremental (10\%) evaporation steps up to $80 \%$ distillate recovery (by volume). Although a full-scale process would likely not have as many evaporation stages, the multi-stage model used in this study enabled a closer look at distillate, brine and solids quality at regular intervals in the thermal desalination process.

To reproduce real-world operating behavior, it was assumed that distillate would be contaminated with brine mist/droplets which escape capture by the mist eliminators. In the process model, mist carryover flow was defined as a percentage of the vapor/distillate flow and was set to approximately $0.01 \%$ by mass. Note that such a mist carryover/contamination will also introduce low volatility organics (in addition to VOCs) and inorganics into the distillate, thus increasing distillate TDS.

Typically, thermal processes operate under vacuum to keep operating temperature low for energy efficiency and to avoid the need for expensive metallurgy. OLI simulations used an operating pressure of $2 \mathrm{psia}(0.14 \mathrm{~atm})$ to be representative of a commercial crystallization operation. The laboratory rotovap system operated at a much lower, standard laboratory vacuum of $0.2 \mathrm{psia}(0.014 \mathrm{~atm})$. This differing pressure was not expected to significantly impact partitioning of inorganic species due to their low volatility. The behavior of volatile organic compounds, however, could be affected by the operating pressure and limited simulation runs were performed to determine differences, if any, between the OLI simulation and laboratory results.

In addition to operating pressure, there were two major differences between the laboratory set up and OLI model. First, in the laboratory tests, $\mathrm{pH}$ of the residual brine $\mathrm{pH}$ was allowed to drift (decrease) because accurate $\mathrm{pH}$ adjustment was determined to be difficult to achieve manually during the course of an on-going experiment. In the OLI model, residual brine $\mathrm{pH}$ was maintained at approximately 6.5 (via caustic addition) to control brine corrosivity to reflect actual operating practice. Second, neutral species such as boron and silica and gases such as ammonia, which are known to be present in unconventional PWs, were not included in OLI. It was believed that such species would not materially impact OLI predictions and it helped to keep the complexity of the OLI model to an acceptable level.

Solid-liquid separation were modelled to show a theoretically pure split between brine liquid and precipitated solids, resulting in a completely dry salt cake. This was done to specifically define/understand the composition of solids generated at each simulation stage. However, it should be recognized that in actual operation it is not possible to achieve total separation, and that the final salt product will be contaminated with constituents that have concentrated in the residual brine.

In summary, PWs are extremely complex from a chemistry perspective, and it would have been impossible to accurately capture all of this complexity in the OLI crystallization model. Therefore, as noted above, the OLI model was set up using reasonable assumptions that were considered to adequately represent the crystallization process for a high-TDS PW.

\subsubsection{Basis and Units Used for Bench Tests and OLI Simulation}

In this study, by convention, the unit of $\mathrm{mg} / \mathrm{L}$ was used for concentration, and where appropriate was converted to ppm or mass $\%$ by applying the brine density determined at each distillate cut. As a realistic indication of the amounts of PW that would be processed at a large operating site, the flow rate of PW was set at 500,000 barrels per day (bbl/day), which is equivalent to $207,394,000$ pounds per day (lb/day). In the laboratory tests, it was easier to collect distillate by volume which is not an option in the OLI model where all stream flow rates and species concentrations were calculated by mass (or moles). To 
facilitate comparison between the laboratory and OLI results, flow rates and concentrations in the laboratory results were converted to a mass basis and are shown in Table 2.

Table 2. Conversion of laboratory volume and laboratory mass $\%$ and distillate cuts set for OLI.

\begin{tabular}{|c|c|c|}
\hline \multicolumn{2}{|c|}{ Lab Distillate Evaporation } & \multirow{2}{*}{$\begin{array}{l}\text { OLI Set Distillate } \\
\text { Cuts, Mass \% }\end{array}$} \\
\hline Volume \% & Mass \% & \\
\hline 10 & 8.5 & 10 \\
\hline 20 & 17.1 & 20 \\
\hline 30 & 25.6 & 29.9 \\
\hline 40 & 34.1 & 39.4 \\
\hline 50 & 42.6 & 49 \\
\hline 60 & 51.2 & 58.6 \\
\hline 70 & 59.7 & 68.4 \\
\hline \multirow{2}{*}{80} & 68.2 & 73.5 \\
\hline & Lab Limit & OLI Limit \\
\hline
\end{tabular}

\subsubsection{Selection and Concentration of Organics Used for OLI Simulation}

As discussed in the introduction, PW can contain a wide range of organic compounds and identification and quantification of these compounds was not a primary focus of this study. The pretreated PW was tested for only for BTEX and the carboxylic acids listed above. For purposes of OLI simulation, this study selected four major classes of organics based on expected partitioning behavior in a thermal desalination system. These, as defined by US EPA, are very-volatile (vVOC), volatile (VOC), semi-volatile (sVOC) and non-volatile (nVOC) organic compounds; representative organics and gases $\left(\mathrm{CO}_{2}\right.$ /alkalinity and $\left.\mathrm{H}_{2} \mathrm{~S}\right)$ and their model input concentrations are listed in Table 3. The nVOC class represented by hexacosane was the only surrogate compound used in this study that had not been previously reported to occur in PW. Rather, it was selected to represent nVOC class behavior and was available in the OLI modelling software.

Table 3. Representative organics profile and gas concentrations used in OLI simulations.

\begin{tabular}{|c|c|c|c|}
\hline Representative Organic Compound & Units & Volatility Classification & Concentration for OLI Model \\
\hline $\mathrm{C}_{2} \mathrm{H}_{6}$ (Ethane) & ppm & vVOC & 3.32 \\
\hline $\mathrm{C}_{3} \mathrm{H}_{8}$ (Propane) & ppm & vVOC & 2.48 \\
\hline $\mathrm{C}_{4} \mathrm{H}_{10}$ (Butane) & ppm & vVOC & 1.83 \\
\hline $\mathrm{C}_{6} \mathrm{H}_{12}$ (Cyclohexane) & ppm & vVOC & 5.28 \\
\hline $\mathrm{C}_{6} \mathrm{H}_{6}$ (Benzene) & ppm & vVOC & 2.95 \\
\hline $\mathrm{C}_{10} \mathrm{H}_{8}$ (Naphthalene) & ppm & VOC & 0.91 \\
\hline $\mathrm{C}_{14} \mathrm{H}_{10}$ (Phenanthrene) & ppm & sVOC & 7.99 \\
\hline $\mathrm{C}_{26} \mathrm{H}_{54}$ (Hexacosane) & ppm & nVOC & 7.96 \\
\hline $\mathrm{C}_{2} \mathrm{H}_{4} \mathrm{O}_{2}$ (Acetate) & ppm & VOC & $42.83 *$ \\
\hline $\mathrm{C}_{3} \mathrm{H}_{6} \mathrm{O}_{2}$ (Propionate) & ppm & VOC & NA \\
\hline $\mathrm{HCO}_{3}-$ (Bicarbonate) & ppm & NA & 5.52 \\
\hline $\mathrm{H}_{2} \mathrm{~S}$ (Hydrogen Sulfide) & ppm & NA & 14.95 \\
\hline
\end{tabular}

* Acetate concentration was adjusted by OLI from as-received $44.6 \mathrm{mg} / \mathrm{L}$ to $42.83 \mathrm{mg} / \mathrm{L}$ due to saturation of acetate in the aqueous phase (water).

\section{Results \& Discussion}

\subsection{Steam Stripping}

Of the carboxylic acids analyzed, PW contained detectable concentrations of acetic and propionic acid at 44.6 and $2.1 \mathrm{mg} / \mathrm{L}$, respectively, and steam stripping resulted in the transport of approximately 1 and $14 \%$ of the mass of these two acids into the condensed distillate (hereafter referred to as $1 \%$ distillate). Consequently, the concentration of acetic acid in the $1 \%$ brine was unchanged while the concentration of propionic acid was proportionately reduced (see Table 4). OLI also predicted low acetate removal during 
steam stripping. Concentration of BTEX in PW and the residual brine was below detection $(<10 \mathrm{ppm})$ while the $1 \%$ distillate contained BTEX at the detection limit of $10 \mathrm{mg} / \mathrm{L}$. Therefore, no definitive conclusion can be drawn with regards to BTEX stripping from PW based on the laboratory data. OLI simulations predicted steam stripping to be very efficient at removing hydrocarbons (across a range of volatility), with typical simulation efficiencies $\geq 99 \%$ except for semi-volatile compound, phenanthrene, which was removed at approximately $97 \%$ (Table 4). Condensate from the steam stripping can be managed by combining it with residual brine (at the end of desalination) and disposal via SWD or it can be evaporated to dryness and disposed as a solid waste.

Table 4. OLI simulation results for organics removal via steam stripping.

\begin{tabular}{|c|c|c|c|c|}
\hline Compound & Classification & $\begin{array}{c}\text { OLI Model Feed } \\
\text { Concentration (ppm) }\end{array}$ & $\begin{array}{c}\text { OLI Predicted } \\
\text { Post-Stripping } \\
\text { Concentration (ppm) }\end{array}$ & $\begin{array}{c}\text { Steam Stripping } \\
\text { Efficiency }\end{array}$ \\
\hline $\mathrm{C}_{2} \mathrm{H}_{6}$ (Ethane) & vVOC & 3.32 & 0.0000006 & $99.999981 \%$ \\
\hline $\mathrm{C}_{3} \mathrm{H}_{8}$ (Propane) & vVOC & 2.48 & 0.0000002 & $99.999990 \%$ \\
\hline $\mathrm{C}_{4} \mathrm{H}_{10}$ (Butane) & vVOC & 1.83 & 0.0000001 & $99.999996 \%$ \\
\hline $\mathrm{C}_{6} \mathrm{H}_{12}$ (Cyclohexane) & vVOC & 5.28 & 0.0000007 & $99.999988 \%$ \\
\hline $\mathrm{C}_{6} \mathrm{H}_{6}$ (Benzene) & vVOC & 2.95 & 0.0008 & $99.97 \%$ \\
\hline $\mathrm{C}_{10} \mathrm{H}_{8}$ (Naphthalene) & VOC & 0.91 & 0.005 & $99.41 \%$ \\
\hline $\mathrm{C}_{14} \mathrm{H}_{10}$ (Phenanthrene) & sVOC & 7.99 & 0.25 & $96.9 \%$ \\
\hline $\mathrm{C}_{26} \mathrm{H}_{54}$ (Hexacosane) & $\mathrm{nVOC}$ & 7.96 & 0.00001 & $99.999868 \%$ \\
\hline & $\mathrm{VOC}$ & 42.8 & 42.4 & $1 \%$ \\
\hline $\mathrm{C}_{2} \mathrm{H}_{4} \mathrm{O}_{2}$ (Acetate) & $\mathrm{VOC}$ & 44.6 (measured) & 44.7 (measured) & $\sim 0 \%$ \\
\hline \multirow{2}{*}{$\mathrm{C}_{3} \mathrm{H}_{6} \mathrm{O}_{2}$ (Propionate) } & \multirow{2}{*}{ VOC } & Not Modeled & Not Modeled & NA \\
\hline & & 2.1 (measured) & 1.8 (measured) & $14 \%$ \\
\hline
\end{tabular}

\subsection{Na and $\mathrm{Cl}$ Partitioning}

Sodium and chloride are the most significant contributors to the TDS in PW. Table 1 shows that the TDS of PW used in this study was approximately 254,000 ppm. Chloride and sodium concentrations were approximately 134,000 ppm and 60,000 ppm, respectively, contributing $75 \%$ of the measured TDS. The partitioning behavior of sodium and chloride during evaporation is therefore expected to have a major impact on process design and operation. Partitioning of chloride, specifically, is a critical factor when selecting materials of construction due to high corrosivity of the residual brine due to elevated $\mathrm{Cl}$ concentration. Laboratory measured average $\mathrm{Na}$ and $\mathrm{Cl}$ concentration in distillate were very low at $4.0 \pm 7.5$ and $0.7 \pm 0.3 \mathrm{mg} / \mathrm{L}$, respectively. OLI predicted somewhat higher average $\mathrm{Na}$ and $\mathrm{Cl}$ concentrations of 5.1 and $14.9 \mathrm{mg} / \mathrm{L}$, respectively (see SI, Figure S2), which includes mist carryover assumed in the OLI model. Generally, OLI predictions for ion concentrations in distillate tended to be somewhat higher than laboratory measured concentrations, suggesting that the assumed mist carryover was higher than actual carryover in the laboratory tests.

While distillate concentrations of various ions/organic species are expressed in $\mathrm{mg} / \mathrm{L}$ (mass/volume) units, the density of brine changes constantly as water is evaporated. Therefore, brine concentrations are more appropriately expressed in mass units (ppm). Figure 4 shows the concentrations of sodium and chloride in the residual brine, which is steadily reduced in volume as more water is evaporated. Chloride is in stoichiometric excess compared with sodium in this PW and its concentration holds constant from about $20 \%$ to $50 \%$ distillate evaporation by mass, indicating $\mathrm{NaCl}$ saturation in this range. Because sodium is the limiting ion, its concentration steadily decreases in this range eventually approaching very low (near-zero) values. Once sodium is nearly depleted in the brine ( $\sim 70 \%$ distillate evaporated by mass), the remaining chloride begins forming salts with calcium and magnesium $\left(\mathrm{CaCl}_{2}\right.$ and $\left.\mathrm{MgCl}_{2}\right)$. OLI prediction of $\mathrm{Na}$ and $\mathrm{Cl}$ concentration in residual brine were in excellent agreement with laboratory measured values. 


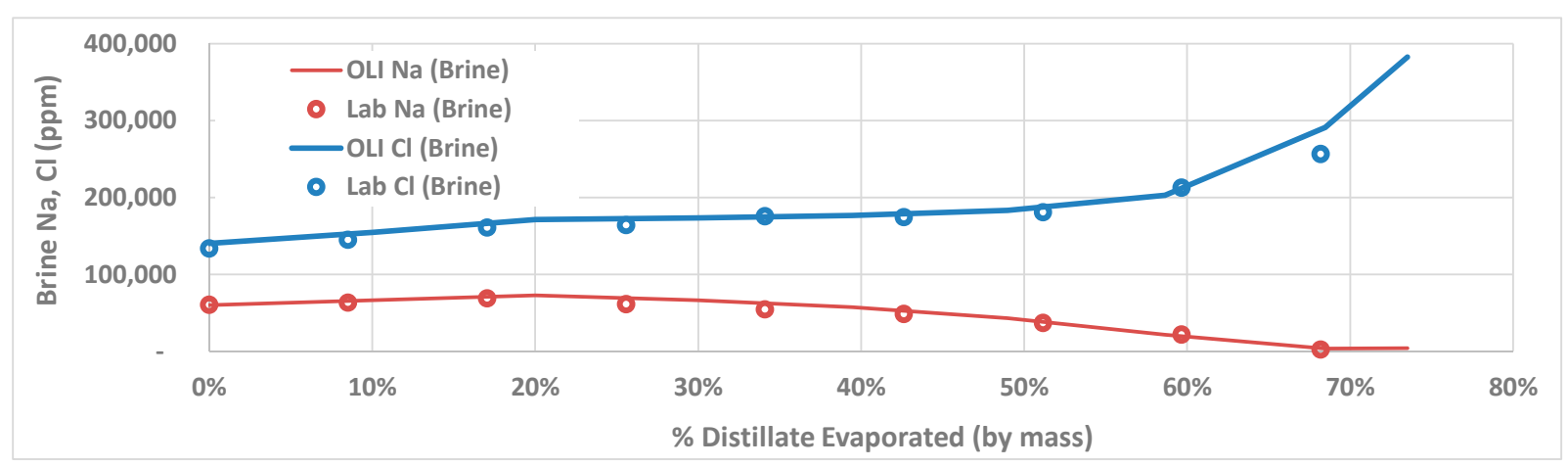

Figure 4. Variation of $\mathrm{Na}$ and $\mathrm{Cl}$ concentration in brine as a function of $\mathrm{PW}$ evaporation.

Note that although the chloride concentration holds relatively constant in $20-50 \%$ evaporation (by mass) range, the total mass of chloride $(\mathrm{lb} / \mathrm{d}$ ) in the residual brine liquid decreases steadily as water is evaporated and chloride gets incorporated into $\mathrm{NaCl}$ solids which precipitate out of solution. Laboratory measured mass flows of sodium and chloride, associated with a PW flow of 500,000 bbl/d, in distillate, brine and salt are shown in Table 5 . Note that both $\mathrm{Na}$ and $\mathrm{Cl}$ are conservative, and therefore, the total mass of $\mathrm{Na}$ (or $\mathrm{Cl}$ ) in $\mathrm{lb} / \mathrm{d}$ at any given evaporation stage should be equal. However, variation in analytical data at very high TDS concentrations typically introduced a measurement error of $\pm 15 \%$. As seen in Table 5 and given that $\mathrm{Na}$ is the limiting ion for $\mathrm{NaCl}$ formation, almost all of the Na partitions into the salt produced by the $68.2 \%$ evaporation point by mass whereas approximately $27 \%$ of the $\mathrm{Cl}$ is still residual in the brine at this stage. The partitioning data therefore showed that past the point of complete $\mathrm{NaCl}$ precipitation, there is sufficient chloride left in the brine to form $\mathrm{Ca}$ and $\mathrm{Mg}$ salts of chloride. Given the high accuracy of prediction, OLI simulations can, therefore, be utilized to accurate model desalination and partitioning of inorganics to generate pure salt fractions from PW.

Table 5. Partitioning of $\mathrm{Na}$ and $\mathrm{Cl}$ between distillate, salt and residual brine as a function of PW evaporation.

\begin{tabular}{|c|c|c|c|c|c|c|}
\hline \multirow{3}{*}{$\begin{array}{l}\text { \% Evaporation } \\
\text { (by mass) }\end{array}$} & \multicolumn{6}{|c|}{ Lab Na Mass Balance (per 500,000 bb/d PW Flow Rate) } \\
\hline & \multicolumn{2}{|c|}{$\mathrm{Na}$ in Distillate } & \multicolumn{2}{|c|}{ Na in Salt } & \multicolumn{2}{|c|}{ Na in Brine } \\
\hline & $1 b / d$ & $\%$ of Total & $\mathrm{lb} / \mathrm{d}$ & $\%$ of Total & lb/d & $\%$ of Total \\
\hline $25.6 \%$ & $5^{1}$ & $0.00004 \%$ & $3,824,666$ & $30 \%$ & $8,793,973$ & $70 \%$ \\
\hline $51.2 \%$ & 11 & $0.00012 \%$ & $5,825,053$ & $67 \%$ & $2,844,700$ & $33 \%$ \\
\hline $68.2 \%$ & 36 & $0.00039 \%$ & $9,260,577$ & $99 \%$ & 50,984 & $1 \%$ \\
\hline \multirow{3}{*}{$\begin{array}{l}\text { \% Evaporation } \\
\text { (by mass) }\end{array}$} & \multicolumn{6}{|c|}{ Lab Cl Mass Balance (per 500,000 bb/d PW Flow Rate) } \\
\hline & \multicolumn{2}{|c|}{$\mathrm{Cl}$ in Distillate } & \multicolumn{2}{|c|}{$\mathrm{Cl}$ in Salt } & \multicolumn{2}{|c|}{$\mathrm{Cl}$ in Brine } \\
\hline & $\mathrm{lb} / \mathrm{d}$ & $\%$ of Total & $\mathrm{lb} / \mathrm{d}$ & $\%$ of Total & $\mathrm{lb} / \mathrm{d}$ & $\%$ of Total \\
\hline $25.6 \%$ & 24 & $0.00008 \%$ & $6,191,558$ & $21 \%$ & $23,573,634$ & $79 \%$ \\
\hline $51.2 \%$ & 41 & $0.00017 \%$ & $9,680,718$ & $41 \%$ & $14,029,539$ & $59 \%$ \\
\hline $68.2 \%$ & 112 & $0.00045 \%$ & $18,307,299$ & $73 \%$ & $6,740,992$ & $27 \%$ \\
\hline
\end{tabular}

Note 1: Based on average distillate Na values (ignoring outliers; see Figure S2).

\subsection{Partitioning of Other Major and Trace Ions}

In the laboratory tests, concentrations of calcium $(\mathrm{Ca})$, magnesium $(\mathrm{Mg})$, barium $(\mathrm{Ba})$, strontium (Sr), potassium (K), boron (B), and sulfate $\left(\mathrm{SO}_{4}{ }^{2-}\right.$ ) were usually less than $1 \mathrm{mg} / \mathrm{L}$ in the distillate (see Supplementary Materials for concentrations). As with $\mathrm{Na}$ and $\mathrm{Cl}$, OLI simulation tended to over-predict the concentration of these ions in the low-TDS distillate stream, likely due to overestimating mist carryover in the process model. Concentrations of $\mathrm{Ca}, \mathrm{Mg}, \mathrm{Ba}, \mathrm{Sr}, \mathrm{K}, \mathrm{B}$ and sulfate in remaining brine are also shown in the Supplementary Materials Section and OLI predictions were generally in good agreement with laboratory measured values up to approximately $68.2 \%$ evaporation by mass. Beyond this point, 
predictions for $\mathrm{Mg}$ and $\mathrm{K}$ were significantly lower than OLI prediction, possibly indicating the removal of these ions by incorporation into precipitated salts.

\subsection{Partitioning of Total Dissolved Solids (TDS)}

TDS in the distillate at various stages of evaporation is shown in Figure 5. Three different TDS values are represented here: (1) OLI TDS-TDS provided by OLI simulation based on input values of various inorganic ions and known organics, (2) laboratory calculated TDS-TDS calculated based on measured concentrations of ions in solution and finally (3) laboratory gravimetric TDS-TDS measured by gravimetic analysis; the gravimetric TDS value also includes any unknown inorganics and organics that partition into the distillate.

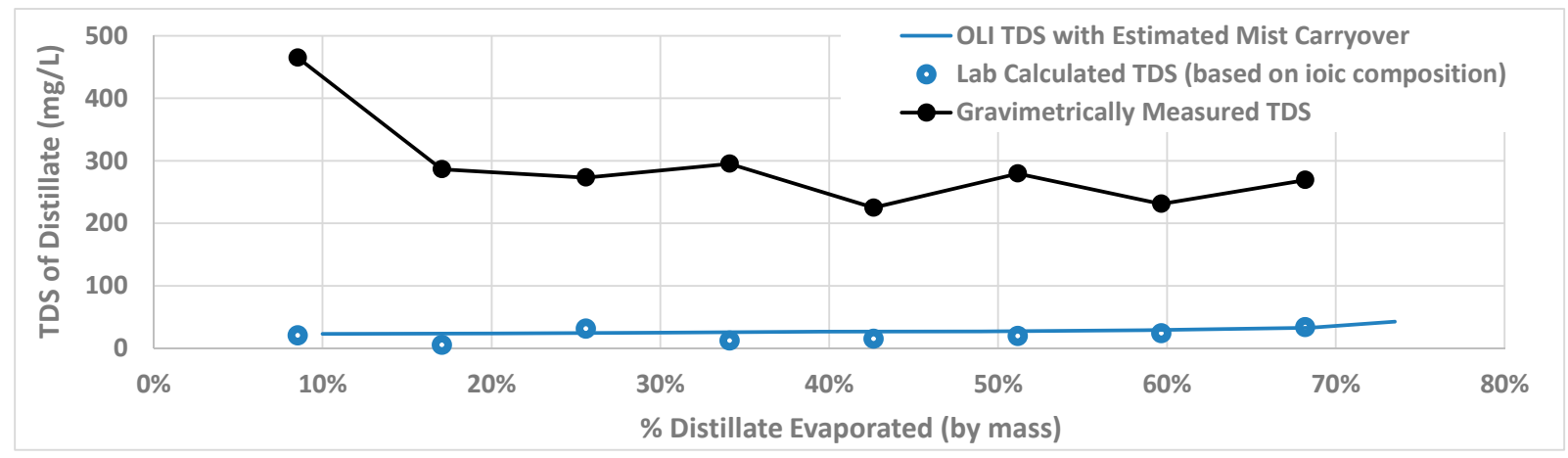

Figure 5. Variation in total dissolved solids (TDS) of distillate as a function of PW evaporation.

TDS estimated by OLI agreed closely with TDS based on measured ionic constituents in the distillate. In both cases, the TDS was typically less than $30 \mathrm{mg} / \mathrm{L}$. However, when the TDS of the distillate was measured gravimetrically, it was typically at least 10 times higher than that predicted by OLI or estimated based on composition of known/analyzed ions.

When alkalinity ions $\left(\mathrm{CO}_{3}{ }^{2-}\right.$ and $\left.\mathrm{HCO}_{3}{ }^{-}\right)$were excluded, a comparison of the cationanion balance in the distillate showed good agreement (Supplementary Materials Figure S10a). Excluding alkalinity ions can be justified given that OLI prediction indicated nearly complete stripping of $\mathrm{CO}_{2}$ (see Table 4 ) and possible interference of organic acids and surfactants during alkalinity analysis. Further, given that the distillate samples were not isolated from the atmosphere, absorption of $\mathrm{CO}_{2}$ into the distillate could have also resulted in a false positive for alkalinity.

Therefore, given the good agreement between cations-anions in the distillate, possible reasons for higher gravimetric TDS in the distillate could be the presence of organics (possibly surfactants based on observed foaming during laboratory experiments), carryover of neutral species and ammonia (which not analyzed or included in the OLI simulation).

Figure 6 shows the TDS of the residual brine liquid phase over the range of distillate evaporated on a mass basis. Ideally, all three curves should have provided close agreement. However, the laboratory results of gravimetric TDS showed consistently higher values than predicted by OLI or based on analyzed species in brine. A comparison of the cationanion balance in the brine showed good agreement (Supplementary Materials Figure S10b). Possible reasons for higher TDS in gravimetric tests include the presence of neutral species (such as $\mathrm{B}$ and $\mathrm{Si}$ ), dissolved gases such as ammonia (poorly stripped due to presence as ammonium ion) and/or unstripped organic compounds. 


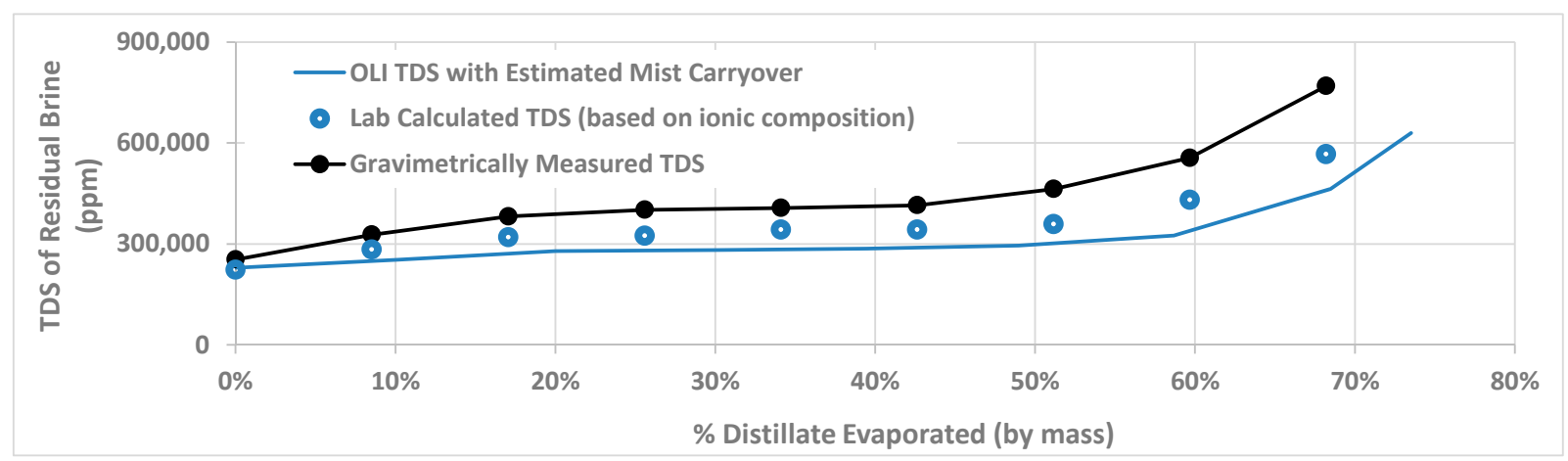

Figure 6. Variation in TDS of residual brine as a function of PW evaporation.

Both the OLI simulation and the laboratory data showed that the TDS of the brine liquid initially increased up to approximately $20 \%$ evaporation. In this range, OLI predicted the precipitation of sparingly soluble sulfate salts- $\mathrm{CaSO}_{4}$ (gypsum) and $\mathrm{SrSO}_{4}$ (celestite). In the range of $25 \%$ to $60 \%$, the TDS stayed relatively constant indicating $\mathrm{NaCl}$ saturation as it precipitated out of solution. As evaporation progressed beyond $60 \%$, water fraction in the residual brine decreased to low levels with very high TDS. At very high TDS, the number of iterations necessary to reach convergence in each calculation block of OLI can exceed user-set limits or result in calculation loops that do not converge to the required accuracy. This can result in excessive simulation run times or termination of the simulation run due to a non-convergence error. For this PW, it was determined that OLI simulation runs were unable to converge (provide a reliable mass balance) above 73.5 mass \% distillate. Laboratory tests showed the evaporation limit to be 68.2 mass \% distillate produced (80\% by volume). When evaporation was increased further to $90 \%$ distillate by volume, the residual brine became a wetted but non-fluid white solid that had insufficient remaining liquid available for analysis (see Figure 7). In actual desalination operation, this wetted solid mixture would not be pumpable, indicating a practical limit of approximately $80 \%$ evaporation (or distillate recovered) by volume.

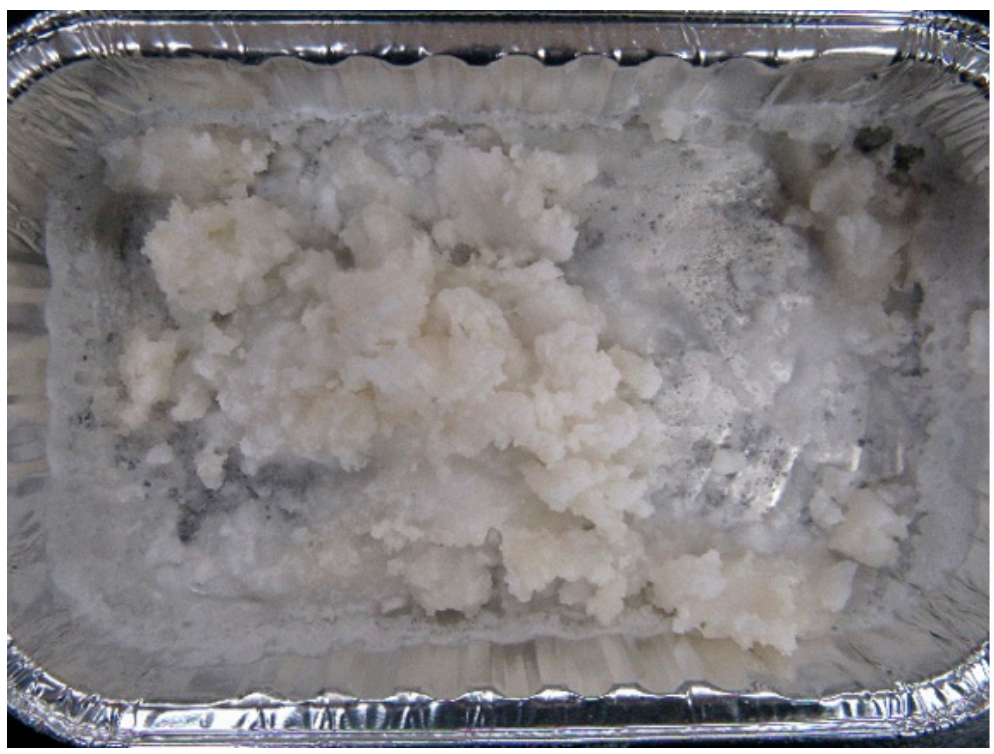

Figure 7. Brine-salt slurry at $90 \%$ evaporation by volume.

\subsection{Partitioning of $\mathrm{Br}, \mathrm{I}$ and $\mathrm{Li}$}

There was negligible partitioning of $\mathrm{Br}, \mathrm{I}$ and $\mathrm{Li}$ into the distillate, with concentrations generally below detection levels (average of $0.4,0.4$ and $0.1 \mathrm{mg} / \mathrm{L}$, respectively). Concentration of $\mathrm{Li}$ and I are likely too low to be viable for economic extraction from the 
original PW itself. However, these ions were preferentially enriched between six to seven times their initial PW concentrations by the $68 \%$ distillate evaporation-mass point and therefore, represent a significant opportunity for resource recovery in the residual brine (see Figure 8).

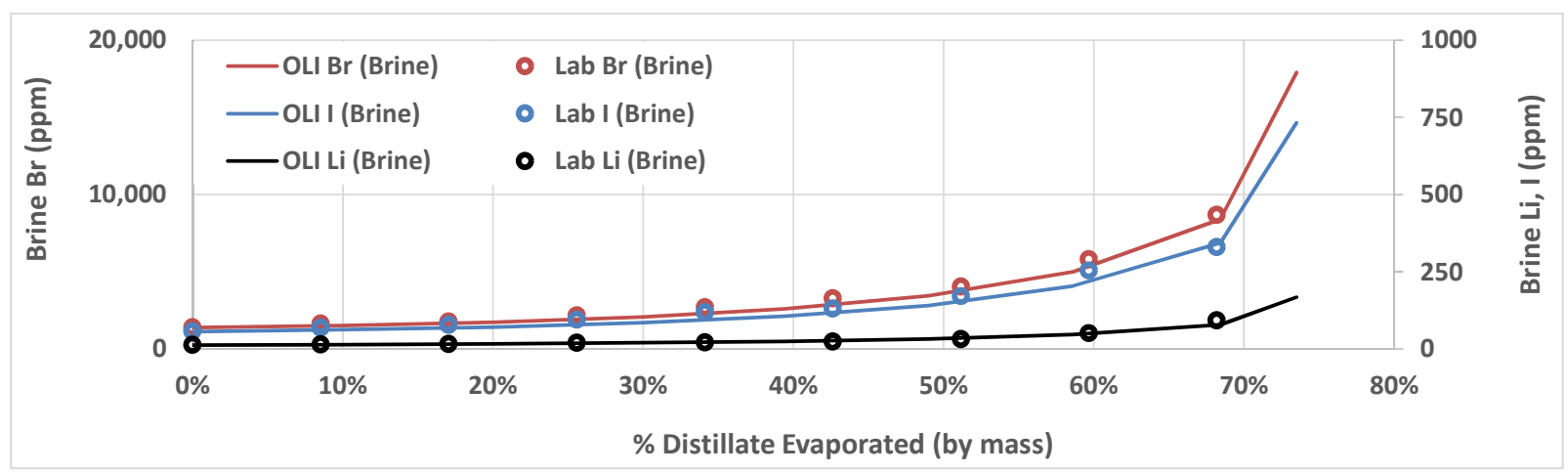

Figure 8. Concentration of bromide, iodide and lithium in brine as a function of PW evaporation.

While the distillate contained very low levels of $\mathrm{Br}$ and I, such trace concentrations can still have potentially adverse ramifications depending on the intended reuse of the distillate (or salt). For example, if the distillate is discharged to a surface water body with a downstream-located drinking water treatment plant, the use of chlorine for disinfection can result in the formation of Br- and I-disinfection by-products (DBPs). Similarly, trace quantities of $\mathrm{Br}$ (or I), if present in salt used for road de-icing, can eventually end up in a surface stream with similar results. At Br concentrations as low as $0.4 \mathrm{mg} / \mathrm{L}$, States et al. [20] showed that DBP mixtures converted from predominantly Cl-DBPs to predominantly $\mathrm{Br}-$ DBPs, thereby greatly increasing the risk profile of the generated DBPs. On the other hand, if distillate (or salt) is used in applications where contact with chlorine is unlikely, the presence of $\mathrm{Br}$ and $\mathrm{I}$ is also unlikely to pose any adverse environmental impacts as these ions pose low inherent toxicity. The above discussion emphasizes the need for careful scenario-dependent evaluation to assess and manage potential health and environmental risks associated with beneficial use of products - both distillate and salt-derived from desalination of PW.

If $\mathrm{Br}$ and/or I removal from distillate is required, there are a number of conventional technologies available including ion exchange [26], granular activated carbon adsorption [27] and nanofiltration [28] which are capable of removing these ions to trace levels.

\subsection{Partitioning of Organics}

To understand partitioning of organics, OLI modeling was used to track partitioning of both hydrophobic and hydrophilic organic compounds listed in Table 3. Due to analytical limitations, the laboratory study tracked BTEX as a surrogate for hydrophobic VOCs and carboxylic acids for hydrophilic VOCs/sVOCs. As noted earlier, most OLI modeling was performed at a pressure of 2 psia to closely match actual plant operating conditions, and a limited number of OLI simulations were performed at the lower laboratory pressure of 0.2 psia.

BTEX concentration in PW was below detection limits and therefore, OLI predictions could not be compared with laboratory data. However, based on OLI predictions for steam stripping, it may be assumed that any hydrophobic organics remaining in brine would efficiently partition into the distillate phase. There was no significant difference in OLI predictions for acetate partitioning at 0.2 and 2.0 psia. At both pressures, OLI predicted virtually no acetate transfer into the distillate $(<0.2 \mathrm{mg} / \mathrm{L})$, indicating nearly complete retention of acetate in the residual brine (see Figure 9 ). In a significant departure from prediction, concentration of acetate in the laboratory distillate (operated at 0.2 psia) increased from an initial concentration of approximately $3-5 \mathrm{mg} / \mathrm{L}$ to nearly $30 \mathrm{mg} / \mathrm{L}$ 
(approximately $46 \%$ by mass, see Figure 10). Although not modeled, partitioning of propionate into the distillate was greater at 95\% (Figure 11).

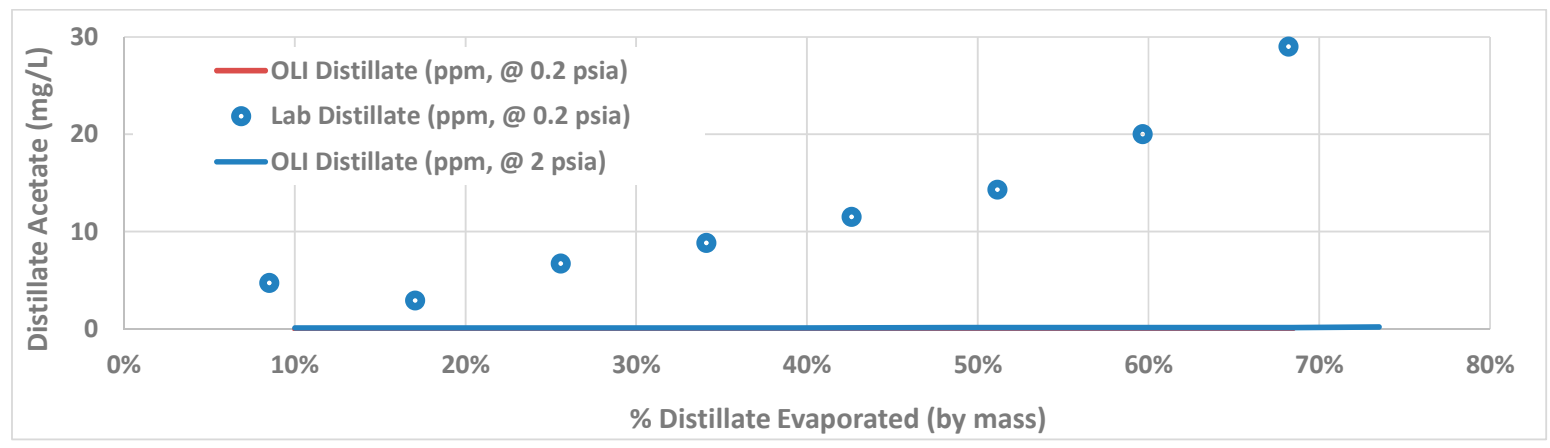

Figure 9. Concentration of acetate in distillate as a function of PW evaporation.

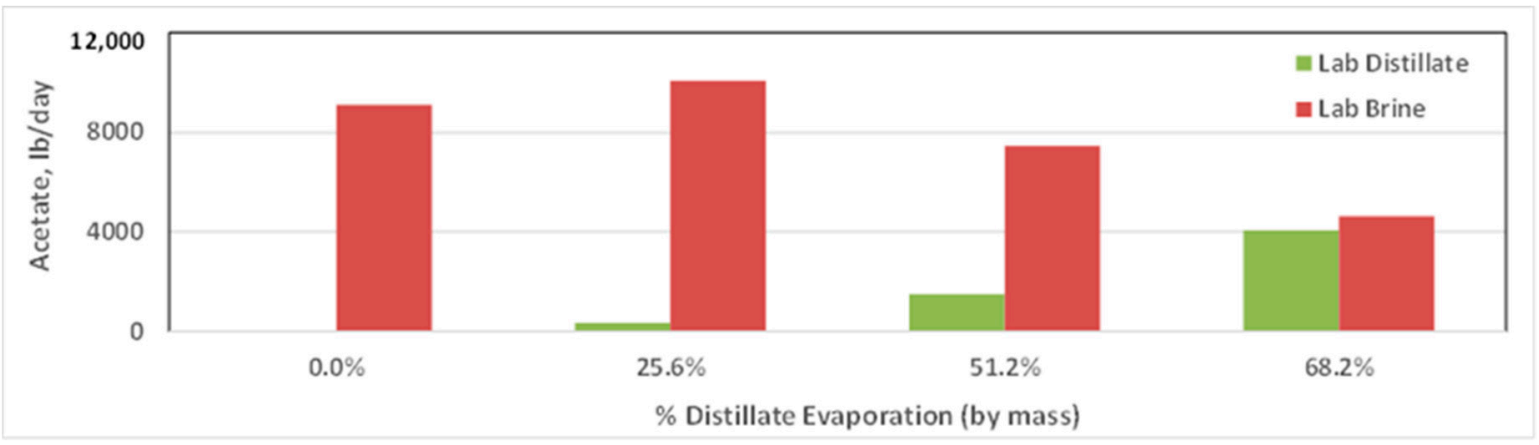

Figure 10. Partitioning of acetate between distillate and brine as a function of PW evaporation.

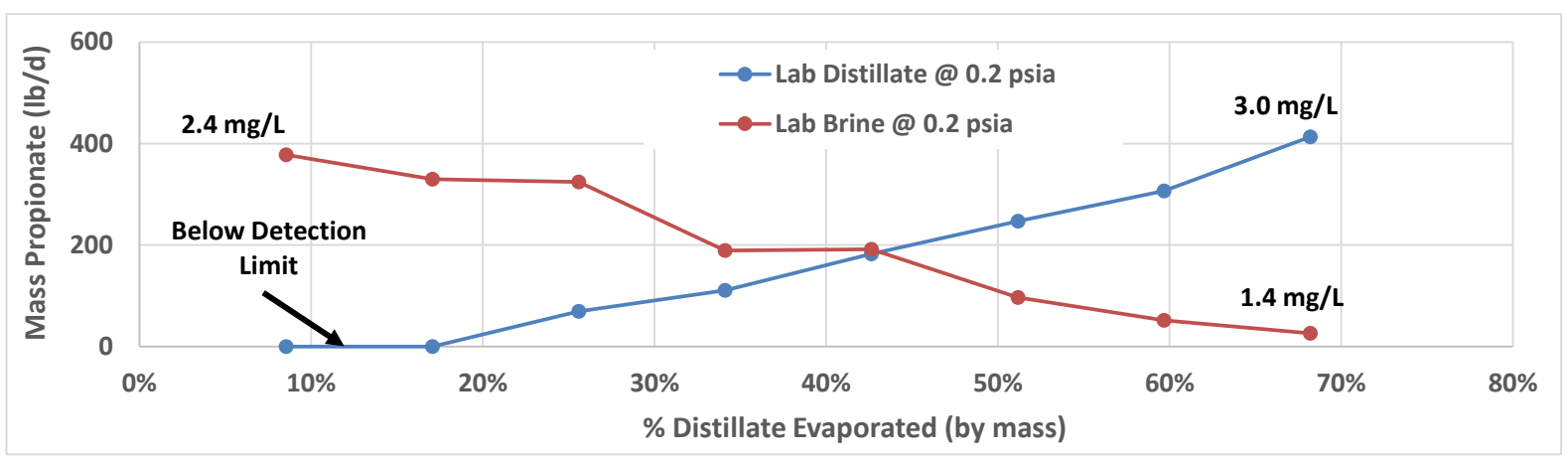

Figure 11. Partitioning of propionate as a function of PW evaporation.

At an initial $\mathrm{pH} 6.5$, acetic acid is predominantly present as acetate and, being a charged species, should have remained in the brine. Based on distillate and brine $\mathrm{pH}$ (see Figure 12), it was hypothesized that the presence of ammonia could have contributed to increased partitioning of acetate into the distillate. To explore this hypothesis, a limited number of OLI simulations were performed with a simplified test brine consisting of sodium, chloride and acetic acid in the presence/absence of ammonia as noted below and the results are shown in Figures 13 and 14. 


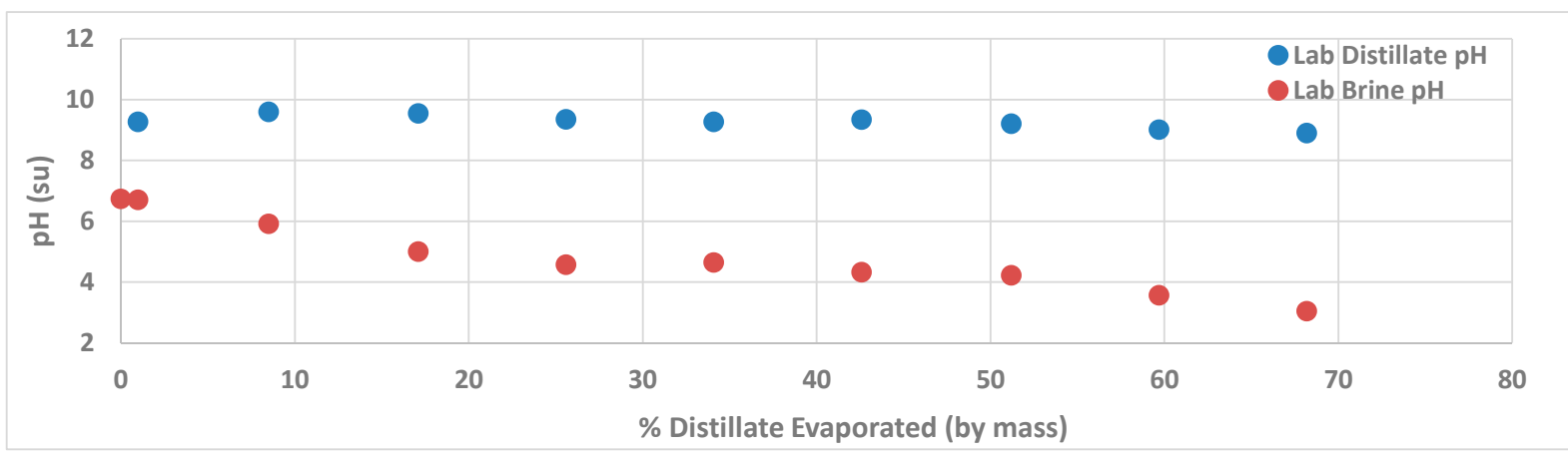

Figure 12. Distillate and brine $\mathrm{pH}$ as a function of $\mathrm{PW}$ evaporation.

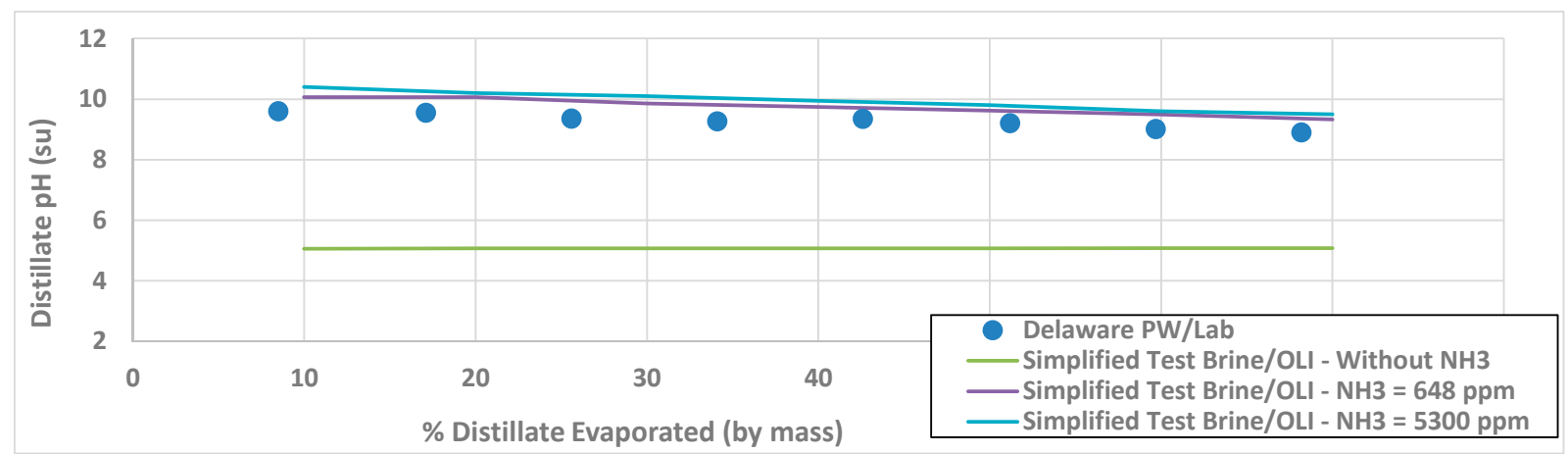

Figure 13. Distillate $\mathrm{pH}$ as a function of ammonia concentration.

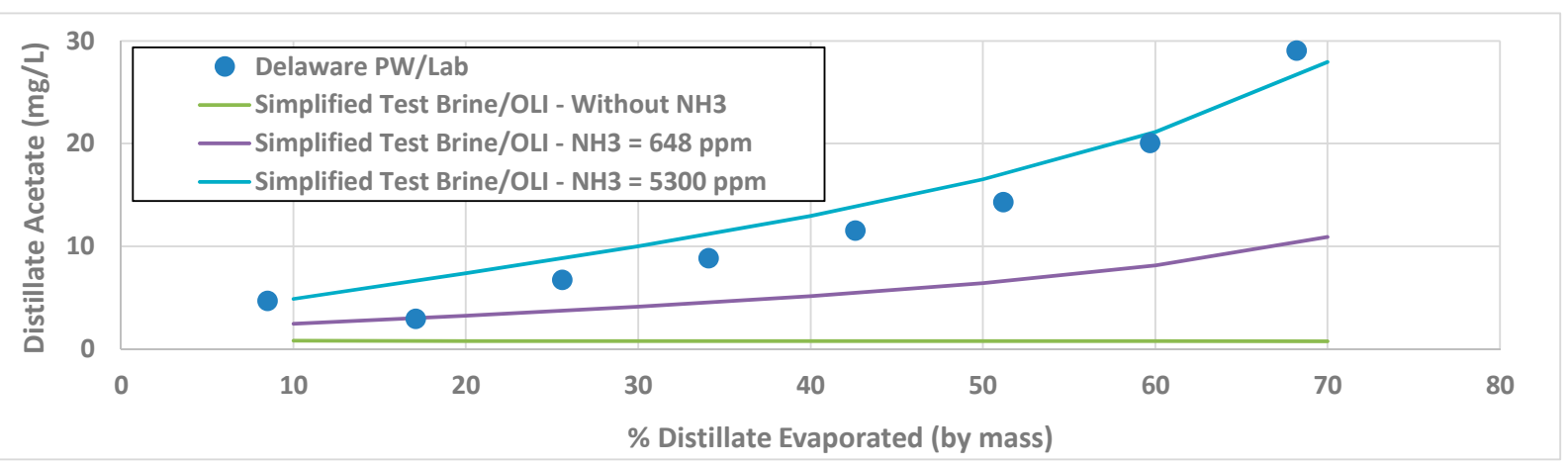

Figure 14. Distillate acetate concentration as a function of ammonia concentration.

Simplified test brine composition:

$\mathrm{Na}=23,000 \mathrm{mg} / \mathrm{L} ; \mathrm{Cl}=35,500 \mathrm{mg} / \mathrm{L}$

acetic acid $=44.4 \mathrm{mg} / \mathrm{L}$

$\mathrm{NH}_{3}=$ varied from 0 to $5300 \mathrm{mg} / \mathrm{L}$

$\mathrm{pH}=6.5$; pressure $=0.2 \mathrm{psia}$ (to match laboratory vacuum)

While the inclusion of ammonia did improve OLI predictions, it required an ammonia concentration of $5300 \mathrm{mg} / \mathrm{L}$ to closely match laboratory distillate acetate concentration. Typical ammonia concentration in PW has been reported at approximately $600 \mathrm{mg} / \mathrm{L}$ [29] and a concentration of $5300 \mathrm{mg} / \mathrm{L}$ in PW was considered unlikely. Based on the laboratory results, the formation of a volatile adduct of acetic acid/acetate and ammonia could explain higher mass transfer of acetate into the distillate at a lower ammonia concentration. The results of the simplified simulation also point to the potential of ammonia to contribute to overall toxicity of the distillate, and the need for removing ammonia to acceptable levels appropriate to the intended beneficial use. 
Total organic carbon (TOC) was measured in the $10 \%, 30 \%$ and $80 \%$ by volume distillate aliquots at 17.4, 8.8 and $16.7 \mathrm{mg} / \mathrm{L}$ (weighted average of $14.8 \mathrm{mg} / \mathrm{L}$ ). Using an average acetate and propionate concentration of 12.3 and $1.5 \mathrm{mg} / \mathrm{L}$ in the laboratory distillate, approximately 4.9 and $0.7 \mathrm{mg} / \mathrm{L} \mathrm{TOC}$, respectively, can be attributed to these two organics. This known TOC comprises approximately $38 \%$ of the average distillate TOC of $14.8 \mathrm{mg} / \mathrm{L}$, and the remaining $62 \%$ of the TOC can, therefore, be attributed to unknown/unanalyzed organics.

The requirement for polishing treatment of the distillate is likely to be a strong function of the end use of the distillate. Both the inherent toxicity of the partitioned organic compounds (if any) and any transformation products post-release will have to be taken into account to ensure that the intended reuse application has a low risk from an environmental perspective. For example, carboxylic acids are readily biodegradable and if there is little/no toxicity associated with other organics in the distillate, polishing treatment may not be necessary. However, if the distillate is used to augment potable supplies, for example via surface discharge upstream of a drinking water treatment plant, then any carboxylic acids, even if posing low inherent toxicity can still serve as precursors to hazardous transformation products such haloacetic acids upon exposure to chlorine which is the most commonly used disinfectant in drinking water treatment plants.

\subsection{Solids Precipitation-Sequence and Characterization}

OLI prediction for solids production is listed in Table 6. Up to $10 \%$ distillate evaporation by mass, no $\mathrm{NaCl}$ is produced and the only solids produced are a result of the precipitation of sparingly soluble sulfate salts of $\mathrm{Ca}$ and $\mathrm{Sr}-\mathrm{gypsum}\left(\mathrm{CaSO}_{4}\right)$ and celestite $\left(\mathrm{SrSO}_{4}\right)$, respectively. Total solids production is approximately 126 tonnes/d (on a dry basis) and given the insolubility of these two sulfate compounds, it should be relatively straightforward to manage these via landfill disposal. However, both gypsum and celestite may also have commercial value. Gypsum is used in wallboard, cement, plaster of Paris and as a soil conditioner. Celestite is the primary ore used for the production of $\mathrm{SrCO}_{3}$ and other Sr compounds, which find application in monitors and ceramic magnets.

$\mathrm{NaCl}$ precipitation starts between $10 \%$ and $20 \%$ evaporation (by mass) points but is still fairly low (less than 500 tonnes/d) and starts precipitating in bulk past the $20 \%$ evaporation point. At the practical limit of approximately $68 \%$ by mass, approximately $99 \%$ of the generated solids is comprised of $\mathrm{NaCl}$ salt (see Table S1 for elemental composition). Extremely soluble chloride salts of $\mathrm{Mg}, \mathrm{K}$ and $\mathrm{Ca}$ remain in solution (brine) at this point. Total solids production at the $68.4 \%$ evaporation (by mass) point is approximately 14,400 tonnes/d (approximately 5.3 M tonnes/y for a flow rate of 500,000 bbl/d), which is almost wholly $\mathrm{NaCl}$. Past this point, additional solids generated are mostly the extremely soluble chloride salts of $\mathrm{Mg}, \mathrm{K}$ and $\mathrm{Ca}$.

A comparison of the solids composition from OLI modelling and laboratory measured solids produced at approximately $68 \%$ evaporation by mass is shown in Table $7 . \mathrm{NaCl}$ salt contained ions such as $\mathrm{Li}, \mathrm{Br}$ and $\mathrm{I}$ which are extremely soluble and should remain in the brine phase. The reason for the decreased purity of salt is due to its moisture content; the moisture being the residual brine from which $\mathrm{NaCl}$ was crystallized. This finding is important as it provides a relatively simple solution to cleaning the salt of such impurities for the purpose of beneficial use. Had these ions been incorporated as part of the solid matrix, it would have been difficult to selectively clean, or remove very soluble ions such as $\mathrm{Br}$ and I, from the salt/solids. However, given that they are present as part of the moisture content, the precipitated salt can be cleaned using a high-purity, NaCl-saturated "starter" brine. As an example, if the impure salt was placed in a column, a slow rinse with the starter brine can displace the impurities present and produce a clean salt that has low /no presence of Br and I ions. The "spent" brine can then either be recycled in the desalination process or disposed via conventional SWD wells. A fraction of the purified salt can then be used to clean subsequent batches of impure salt. However, it should be noted that further processing (purification) of salt will incur additional costs for a product that is already a 
low-value bulk commodity, and the economic feasibility of purification will have to be determined.

Table 6. OLI predicted solids production from desalination of 500,000 bbl/d of PW.

\begin{tabular}{|c|c|c|c|c|c|c|c|c|}
\hline \multirow{3}{*}{ Compound } & \multicolumn{8}{|c|}{ \% Distillate Evaporation by Mass-OLI Prediction } \\
\hline & $10.0 \%$ & $20.0 \%$ & $29.9 \%$ & $39.4 \%$ & $49.0 \%$ & $58.6 \%$ & $68.4 \%$ & $73.5 \%$ \\
\hline & \multicolumn{8}{|c|}{$\%$ Of total solid species } \\
\hline $\mathrm{NaCl}$ (Halite) & & 77.7 & 96.6 & 98.1 & 98.7 & 98.9 & 99.0 & 80.4 \\
\hline $\mathrm{CaSO}_{4}$ (Anhydrite) & 82.1 & 18.6 & 2.8 & 1.6 & 1.1 & 0.9 & 0.8 & 0.7 \\
\hline $\mathrm{SrSO}_{4}$ (Celestite) & 17.5 & 3.7 & 0.5 & 0.3 & 0.2 & 0.2 & 0.2 & 0.1 \\
\hline $\mathrm{MgCl}_{2} \cdot 2 \mathrm{CaCl}_{2} \cdot 6 \mathrm{H}_{2} \mathrm{O}$ & & & & & & & & 18.3 \\
\hline $\mathrm{KCl} . \mathrm{CaCl}{ }_{2}$ (Chlorocalcite) & & & & & & & & 0.4 \\
\hline \multirow[t]{2}{*}{ Sodium Aluminosilicate gel } & 0.3 & 0.07 & 0.01 & 0.005 & 0.004 & 0.003 & 0.003 & 0.002 \\
\hline & \multicolumn{8}{|c|}{ Tonnes/d } \\
\hline Total Dry Solids @ 500,000 bbl/d & 126 & 593 & 4027 & 7259 & 10,384 & 13,128 & 14,418 & 17,843 \\
\hline
\end{tabular}

Table 7. Comparison of OLI predicted and laboratory measured ions in solids production at 68.2\% evaporation (by mass).

\begin{tabular}{ccc}
\hline Ion & $\begin{array}{c}\text { OLI Predicted Concentration in Solids at 68.4\% } \\
\text { Evaporation by mass (ppm) }\end{array}$ & $\begin{array}{c}\text { Lab Measured Concentration in Solids at 68.2\% } \\
\text { Evaporation by mass (ppm) }\end{array}$ \\
\hline $\mathrm{Al}$ & 2.5 & 8.1 \\
$\mathrm{Ba}$ & 0.2 & $<0.1$ \\
$\mathrm{~B}$ & 0.8 & 29.0 \\
$\mathrm{Ca}$ & 37,397 & 47,973 \\
$\mathrm{Fe}$ (total) & $\mathrm{NP}$ & $<0.3$ \\
$\mathrm{Li}$ & $\mathrm{NP}$ & 19.0 \\
$\mathrm{Mg}$ & 20 & 6330 \\
$\mathrm{Mn}$ & $\mathrm{NP}$ & 10.7 \\
$\mathrm{~K}$ & 935 & 5481 \\
$\mathrm{Si}$ & 22 & 8 \\
$\mathrm{Na}$ & 389,500 & 264,907 \\
$\mathrm{Sr}$ & 731 & 3455 \\
$\mathrm{Br}$ & $\mathrm{NP}$ & 3186 \\
$\mathrm{Cl}$ & 600,647 & 523,696 \\
$\mathrm{I}$ & $\mathrm{NP}$ & 110 \\
$\mathrm{SO}_{4}{ }^{2-}$ & 2203 & 1601 \\
\hline
\end{tabular}

Note 1: NP-Not present.

Based on laboratory results, at the point of practical desalination limit of $80 \%$ evaporation by volume, approximate distillate, salts and remaining brine quantities are shown in Table 8 below.

Table 8. Mass balance for desalination and polishing treatment (pre- and post-desalination) into product and waste streams.

\begin{tabular}{ccc}
\hline Parameter & Value & Remarks/Assumptions \\
\hline Untreated PW Flow Rate: & $510,200 \mathrm{bbl} / \mathrm{d}$ & \\
Pretreated PW Flow Rate: & $500,000 \mathrm{bb} / \mathrm{d}$ & assuming $2 \%$ pretreatment water loss \\
Distillate Recovered: & $400,000 \mathrm{bb} / \mathrm{d}$ & assuming $80 \%$ recovery by volume \\
Polished Distillate Recovered: & $392,000 \mathrm{bbl} / \mathrm{d}$ & assuming $2 \%$ polishing treatment water loss \\
Mass CaSO $4:$ & $261,143 \mathrm{lb} / \mathrm{d}(\mathrm{dry})$ & \\
Mass $\mathrm{SrSO}_{4}:$ & $48,717 \mathrm{~b} / \mathrm{d}(\mathrm{dry})$ & \\
Mass NaCl: & $31,472,340 \mathrm{lb} / \mathrm{d}(\mathrm{dry})$ & at a bulk density of $2.16 \mathrm{~g} / \mathrm{cc}$ \\
Volume NaCl: & $233,565 \mathrm{ft} / \mathrm{d}$ & including 5000 bbl $/ \mathrm{d}$ stripped steam condensate \\
Remaining Brine, Mass: & $35,942,100 \mathrm{lb} / \mathrm{d}$ & at a density of $1.39 \mathrm{~g} / \mathrm{cc}$ \\
Remaining Brine, Volume: & $73,397 \mathrm{bbl} / \mathrm{d}$ & dry; remaining brine evaporated to dryness \\
Mixed Salt Waste, Mass & $15,828,900 \mathrm{lb} / \mathrm{d}$ & at a bulk density of $3.09 \mathrm{~g} / \mathrm{cc}$ \\
Mixed Salt Waste, Volume: & $82,111 \mathrm{ft} / \mathrm{d}$ &
\end{tabular}


Based on the above discussion, it can be seen that desalination of PW will produce large quantities of solids. While a small fraction of the solids precipitated are sparingly soluble and can be sent to traditional landfills, a majority of the solids production $(>99 \%)$ will be comprised of extremely soluble salts such as $\mathrm{NaCl}$ and the mixed salt waste left over at the end of evaporation. Such soluble solids cannot be sent to traditional landfills, which typically limit the soluble content of the solid waste accepted. Therefore, salt and other soluble solids may have to be transported to special landfills designed to accept highly soluble waste.

To put this large quantity of salt in perspective, and assuming that a typical dump truck can handle (the lesser of) 14 cubic yards /42,000 lbs of load, it would take approximately 750 trucks / $\mathrm{d}$ to haul the $\mathrm{NaCl}$ salt produced from a 500,000 bbl/d desalination facility to a landfill. The leftover brine, if trucked to a SWD facility, will require another 814 trucks/d, which reduces to 377 trucks/d if the leftover brine is evaporated to dryness (zero-liquid discharge option).

\subsection{Resource Extraction- $\mathrm{Li}, \mathrm{Br}$ and I}

To determine if ions such as $\mathrm{Li}, \mathrm{Br}$ and I in PW are preferentially depleted or enriched when compared with seawater, the ratios of these ions to chloride were determined after normalizing for TDS (see Table 9). The ratios of Li, Br and I ions:chloride in PW clearly show that these ions are preferentially enriched in PW when compared with seawater with Br showing the lowest enrichment at 3.1X and Iodine showing the highest enrichment at 230X. The ratios of $\mathrm{Li}: \mathrm{Cl}, \mathrm{Br}: \mathrm{Cl}$ and I: $\mathrm{Cl}$ were also examined as a function of oil and gas producing formation and plotted against a seawater evaporation curve (see SI, Figure S12a-c, respectively). With the caveat that there are limited data on I available in literature (it is not a routinely analyzed ion), the data clearly indicate preferential enrichment of $\mathrm{Li}, \mathrm{Br}$ and I typical of evaporite deposits in unconventional PWs.

Table 9. Preferential enrichment of Br, I and Li in Delaware Basin PW.

\begin{tabular}{ccccc}
\hline Water Quality & Delaware & Typical & (Prod Water)/ & Enrichment \\
\hline Parameter & Average & Seawater & (Seawater) & Factor \\
\hline TDS & 210,254 & 35,000 & 6.01 & 1.0 \\
Br & 1203 & 65 & 18.5 & 3.1 \\
I & 60 & 0.043 & 1381 & 230 \\
Li & 51 & 0.180 & 283 & 47 \\
\hline
\end{tabular}

Note 1: All concentrations expressed in mg/L. Note 2: The "Delaware Average" was calculated from data available for 87 wells from formations including the Delaware Mountain Group, Bone Springs, Devonian, Wolfcamp and Upper and Lower Avalon.

There are a number of technologies currently available to extract Li from PW including solvent extraction and selective ion exchange. Bromine may be recovered using a selective electrolysis process such as the one reported by Sun et al. [30]. Therefore, these ions present an opportunity for extraction from either the original PW or concentrated brines from a desalination process. Using bulk prices of $\$ 63, \$ 5$ and $\$ 26 / \mathrm{kg}$ of $\mathrm{Li}, \mathrm{Br}$ and $\mathrm{I}$, the value of these three elements based on PW concentration listed in Table 1 and a flow rate of $500,000 \mathrm{bbl} / \mathrm{d}$ is approximately $\$ 65,000, \$ 555,000$ and $\$ 117,000 / \mathrm{d}$, respectively. While unlikely to offset the considerable cost of desalination of unconventional PWs, the extraction of these three and other elements that may be present in PW (such as rare earth elements and $\mathrm{Sr}$ ) still offers a potential prize that merits further investigation.

\section{Conclusions}

In this study, the partitioning of various constituents in PW was studied using a bench-top crystallizer and compared with OLI model predictions. Laboratory studies were limited to approximately $68 \%$ by mass ( $80 \%$ by volume) before the residual solids and brine mixture became too viscous to continue evaporation. The limit for the OLI model 
was slightly higher at $73 \%$ before the software was unable to converge to a solution, likely due to the non-ideal behavior of ions at very high ionic strength.

The incorporation of a steam stripping step was determined to be effective at removing hydrophobic organic compounds from PW. Steam stripping can also serve to reduce alkalinity (through stripping of $\mathrm{CO}_{2}$ ) and thereby reduce/prevent the formation of calcite and other carbonate solids.

Both OLI and laboratory measurements indicated very low carryover of inorganics into the distillate although numerically, OLI model predictions generally over-predicted distillate inorganic concentrations. Both distillate and residual brine contained unknown constituents that resulted in significantly higher gravimetrically determined TDS. This difference was attributed to the presence of neutral species, dissolved gases (such as $\mathrm{NH}_{3}$ or $\mathrm{H}_{2} \mathrm{~S}$ ) (not analyzed or included as input ions in $\mathrm{OLI}$ ) and unknown organic compounds including surfactants based on observed foaming during evaporation.

Based on OLI predictions, any residual hydrophobic organics in PW post-stream stripping should partition into the distillate. In contrast to negligible predicted transfer of acetate to distillate, approximately $46 \%$ transfer by mass was observed in the laboratory tests. Although not modeled, propionate transfer to the distillate was higher at $95 \%$. Inclusion of ammonia as input species greatly improved the match between OLI prediction and laboratory results. Based on observed results, it was hypothesized that acetic acid/acetate and ammonia may have formed a volatile adduct that increased the partitioning of both species into the distillate. Approximately $38 \%$ of the TOC in the distillate could be attributed to known organics. Depending on the end use of the distillate, polishing treatment may be required to remove residual organics and ammonia to acceptable levels. Organics in distillate are likely to be hydrophilic compounds, which are generally more amenable to biodegradation. While the concentration of DBP-forming ions such as bromide and iodide in the distillate was low, the potential for these compounds to serve as precursors of hazardous transformation products post-release into the environment will have to be assessed and if unacceptable risk is identified, mitigation measures will need to be designed to reduce risk to an acceptable level.

As PW was evaporated, sparingly soluble sulfate salts of Ca and Sr precipitated first followed by bulk $\mathrm{NaCl}$ precipitation and finally extremely soluble $\mathrm{Cl}$ salts of $\mathrm{Mg}$, $\mathrm{K}$ and $\mathrm{Ca}$. Model predictions can be utilized to control the desalination process in order to generate high purity salts, which can increase their marketability. Desalination of PW generated very large quantities of soluble salts, including approximately 14,400 tonnes of $\mathrm{NaCl} / \mathrm{d}$

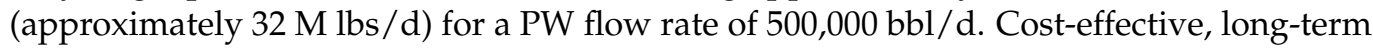
management of $\mathrm{NaCl}$ and other salts is therefore imperative, if beneficial use is to be developed as a viable option for PW management. Impurities such as highly soluble Br and I ions in $\mathrm{NaCl}$ are likely due to the moisture content of the salt and not a result of precipitation, which indicates that washing with a clean, saturated $\mathrm{NaCl}$ solution can be an effective approach for obtaining high purity $\mathrm{NaCl}$. Finally, after normalizing for TDS, the ratios of $\mathrm{Li}, \mathrm{Br}$ and I to chloride in $\mathrm{PW}$ were much greater when compared with their ratios in seawater indicating enrichment of these ions in PW and potential for commercial recovery of these ions.

\section{Recommendations for Future Research}

\subsection{Improvements to Laboratory Setup and OLI Model for Partitioning Studies}

Produced water is a complex mixture and the laboratory setup and OLI model used in this study attempted a simple/manageable interpretation of this complex mixture. To improve understanding of PW constituent partitioning behavior and obtain a more accurate mass balance of various constituents upon thermal desalination, the following improvements are recommended:

1. Analysis of neutral species such as boron and silica in PW, brine and distillate and their inclusion in the OLI model; 
2. Regular $\mathrm{pH}$ adjustment in laboratory tests to match model inputs for accurate prediction of constituents such as carboxylic acids and ammonia whose speciation and, therefore, partitioning behavior can be $\mathrm{pH}$-dependent;

3. Operation of laboratory setup at an appropriate pressure/temperature regime to closely match full-scale process(es);

4. Greater characterization of the organic constituents (especially halogenated organics) in raw/untreated $\mathrm{PW}$, which can then be input into OLI to study partitioning behavior.

5. In the event that inorganic or organics constituents of interest are either not present in PW or their concentration is below detection limits, these constituents can be spiked into PW to detectable levels such that they can be tracked both analytically and via OLI simulation.

\subsection{Partial Evaporation of $P W$ for Volume Reduction}

While most of the discussion regarding PW management and beneficial use among various stakeholders is focused on desalination, there has been little attention given to the possibility of partial evaporation of PW. One major drawback of "full" evaporation/desalination is the generation of extremely large amounts of various solids/salts. However, if PW is only partially evaporated/concentrated such that the residual brine is still below saturation level of halite, the amount of solids generated can be greatly reduced. The magnitude of volume reduction will depend on the difference between the starting TDS and saturation levels for major ions in PW. If the starting TDS is low, a significant amount of distillate can be recovered for beneficial use with an accompanying reduction in volume of PW that can be sustainably disposed of in SWD wells.

\subsection{Opportunistic Partial Evaporation or Desalination}

Given that TDS of PWs can vary significantly, both temporally and spatially, real-time monitoring of producing wells for TDS and flow rate can be used to opportunistically target those PWs with low TDS and high flow rates. A case-by-case basis/evaluation can be made to employ either partial evaporation or desalination such that solid waste is minimized while still recovering substantial quantities of distillate for beneficial use.

\subsection{Off-Basin/Inter-State Transfers of Excess PW}

To date, alternative approaches to manage excess PW have been solely focused on treatment options. This is in part due to regulatory constraints which make it difficult to transfer PW across state boundaries. For example, conventional O\&G operations in TX require large quantities of water for pressure maintenance. An alternate approach could consider the transport of excess PW from NM to other states such as TX for reservoir pressure maintenance and other uses within the $O \& G$ industry. A variation of this approach could combine partial evaporation with transport of the residual brine across state boundaries. Such as approach appears attractive for the following reasons. The use of partial evaporation would ensure that the distillate, with polishing treatment if necessary, is available for beneficial use in NM. Any solid waste generated would be composed mostly of sparingly soluble salts ( $\mathrm{Ca}$ and $\mathrm{Sr}$ salts of sulfate) and its long-term management in landfills is less challenging than highly soluble waste (such as $\mathrm{NaCl}$ ). The removal of sparingly soluble gypsum and celestite also offers another advantage in that the residual brine now comprises ions that are extremely soluble, which makes long term transport via pipelines less problematic due to the elimination of scaling ions. Furthermore, the removal of ions such as sulfate also increases the likelihood that the residual brine is compatible with the formations where it is injected for pressure maintenance due to reduced likelihood of scaling and souring potential. The use of residual brine thus offers the donor state the benefit of recovering distillate with little to no waste generation and the receiving state the advantage of being able to offset fresh water use. 


\subsection{The Need for a Holistic Cost-Benefit Analysis of Desalination and Beneficial Use}

Recent research on beneficial use have focused on PW characterization and desalination technologies. This singular focus on characterizing PW quality and developing novel technologies for desalination leaves no/limited space for an informed comparison of costs, benefits and risks associated with various treatment and beneficial use options. Therefore, a holistic approach is required to compare various PW management alternatives using the metrics noted below.

1. Long-term projections of PW available for beneficial use after accounting for:

(a) Spatial and temporal variability of PW generation,

(b) SWD capacity and internal reuse, and

(c) Net recovery of treated/desalinated PW (process recovery minus water footprint of energy required for desalination).

2. Life-cycle costs of various management options including impact of declining rates of PW generation on already built infrastructure (for example, desalination plants, energy requirements and associated infrastructure, transportation networks, etc.).

3. Environmental aspects of various PW management options including:

(a) Use-specific identification of acceptable toxicity end-points for various beneficial uses and design of mitigation measures (if required),

(b) Energy requirement $(\mathrm{kWh} / \mathrm{bbl})$, greenhouse gases $(\mathrm{GHG})$ and air emissions considerations, and

(c) Waste generation and its sustainable, long-term management.

Supplementary Materials: The following are available online at https:/ / www.mdpi.com/article/10 $.3390 / w 13081068 /$ s1, Figure S1: Block Flow Diagram of a typical thermal desalination process for high TDS produced water treatment; Figure S2: Variation in $\mathrm{Na}$ and $\mathrm{Cl}$ concentration in Distillate as a function of PW Evaporation; Figure S3(a): Variation in $\mathrm{Na}$ and $\mathrm{Cl}$ concentration in Distillate as a function of PW Evaporation; Figure S3(b): variation in Ca concentration in Brine as a function of PW Evaporation; Figure S4(a): Variation in Mg concentration in Distillate as a function of PW Evaporation; Figure S4(b): variation in Mg concentration in Brine as a function of PW Evaporation; Figure S5(a): Variation in Ba concentration in Distillate as a function of PW Evaporation; Figure S5(b): variation in Ba concentration in Brine as a function of PW Evaporation; Figure S6(a): Variation in Sr concentration in Distillate as a function of PW Evaporation; Figure S6(b): variation in Sr concentration in Brine as a function of PW Evaporation; Figure S7(a): Variation in K concentration in Distillate as a function of PW Evaporation; Figure S7(b): variation in K concentration in Brine as a function of PW Evaporation; Figure S8(a): Variation in B concentration in Distillate as a function of PW Evaporation; Figure S8(b): variation in B concentration in Brine as a function of PW Evaporation; Figure S9(a): Variation in Sulfate concentration in Distillate as a function of PW Evaporation; Figure S9(b): variation in Sulfate concentration in Brine as a function of PW Evaporation; Figure S10(a): Cation-Anion Balance in Distillate as a function of PW Evaporation; Figure S10(b): Cation-Anion Balance in Brine as a function of PW Evaporation; Figure S11(a): Concentration of Acetate in residual brine as a function of PW Evaporation; Figure S11(b): $\mathrm{pH}$ of simplified test brine as a function of ammonia and PW Evaporation; Figure S12(a): pH of simplified test brine as a function of ammonia and PW Evaporation; Figure S12(b): Preferential enrichment of Bromide in PW compared with seawater for Delaware Basin formations; Figure S12(c): Preferential enrichment of Iodide in PW compared with seawater for formations from the Delaware, Marcellus and Bakken Basins; Table S1: Elemental composition of solids at three evaporation cuts (by mass).

Author Contributions: Concept origination, G.L.G.; study execution and methodology, G.L.G., D.M. and L.L.; modeling, L.L., D.M. and G.L.G.; data analysis and validation, G.L.G., L.L. and D.M.; writing-original draft preparation, G.L.G.; writing-review and editing, G.L.G., D.M. and L.L.; overall supervision, G.L.G.; project administration-ExxonMobil Upstream Research Company, G.L.G.; project administration-Advisian, D.M. All authors have read and agreed to the published version of the manuscript.

Funding: This project was funded by the ExxonMobil Upstream Research Company. 
Institutional Review Board Statement: Not applicable.

Informed Consent Statement: Not applicable.

Data Availability Statement: Not applicable.

Acknowledgments: The authors would like to acknowledge the following individuals for providing an expert review and/or editorial comments for this manuscript: Tom F. Parkerton (retired) and Karen P. Christensen (retired) (ExxonMobil Biomedical Sciences), and Carlos Galdeano and Eric J. Febbo (ExxonMobil Upstream Research Company).

Conflicts of Interest: The authors declare that they have no known competing financial interests or personal relationships that could have appeared to influence the work reported in this paper.

\section{References}

1. Veil, J. US Produced water volumes and management practices in 2017. In Ground Water Research and Education Foundation; Ground Water Protection Council, Inc.: Oklahoma City, OK, USA, 2020. Available online: http:/ /www.veilenvironmental.com/ publications/pw/pw_report_2017_final.pdf (accessed on 2 February 2021).

2. State of New Mexico and US EPA. Oil and Natural Gas Produced Water Governance in the State of New Mexico-Draft White Paper; 2018 Available online: https:/ /www.epa.gov/sites/production/files/2018-11/documents / oil_and_natural_gas_produced_water_ governance_in_the_state_of_new_mexico_draft_white_paper_508.pdf (accessed on 4 February 2021).

3. Scanlon, B.R.; Reedy, R.C.; Xu, P.; Engle, M.; Nicot, J.; Yoxtheimer, D.; Yang, Q.; Ikonnikova, S. Can we beneficially reuse produced water from oil and gas extraction in the U.S.? Sci. Total. Environ. 2020, 717, 137085. [CrossRef]

4. Engle, M.A.; Blondes, M.S. Linking compositional data analysis with thermodynamic geochemical modeling: Oilfield brines from the Permian Basin, USA. J. Geochem. Explor. 2014, 141, 61-70. [CrossRef]

5. Harkness, J.S.; Dwyer, G.S.; Warner, N.R.; Parker, K.M.; Mitch, W.A.; Vengosh, A. Iodide, Bromide, and Ammonium in Hydraulic Fracturing and Oil and Gas Wastewaters: Environmental Implications. Environ. Sci. Technol. 2015, 49, 1955-1963. [CrossRef]

6. $\quad$ Lester, Y.; Ferrer, I.; Thurman, E.M.; Sitterley, K.A.; Korak, J.A.; Aiken, G.; Linden, K.G. Characterization of hydraulic fracturing flowback water in Colorado: Implications for water treatment. Sci. Total Environ. 2015, 512-513, 637-644. [CrossRef]

7. McLaughlin, M.C.; Borch, T.; McDevitt, B.; Warner, N.R.; Blotevogel, J. Water quality assessment downstream of oil and gas produced water discharges intended for beneficial use in arid regions. Sci. Total Environ. 2020, 713, 136607. [CrossRef]

8. Niemeyer, J.C.; Medici, L.O.; Correa, B.; Godoy, D.; Ribeiro, G.; Lima, S.D.O.F.; de Santo, F.B.; de Carvalho, D.F. Treated produced water in irrigation: Effects on soil fauna and aquatic organisms. Chemosphere 2020, 240, 124791. [CrossRef] [PubMed]

9. Burgos, W.D.; Castillo-Meza, L.; Tasker, T.L.; Geeza, T.J.; Drohan, P.J.; Liu, X.; Landis, J.D.; Blotevogel, J.; McLaughlin, M.; Borch, T.; et al. Watershed-Scale Impacts from Surface Water Disposal of Oil and Gas Wastewater in Western Pennsylvania. Environ. Sci. Technol. 2017, 51, 8851-8860. [CrossRef] [PubMed]

10. Butkovskyi, A.; Bruning, H.; Kools, S.A.; Rijnaarts, H.H.; Van Wezel, A.P. Organic Pollutants in Shale Gas Flowback and Produced Waters: Identification, Potential Ecological Impact, and Implications for Treatment Strategies. Environ. Sci. Technol. 2017, 51, 4740-4754. [CrossRef] [PubMed]

11. Danforth, C.; Chiu, W.A.; Rusyn, I.; Schultz, K.; Bolden, A.; Kwiatkowski, C.; Craft, E. An integrative method for identification and prioritization of constituents of concern in produced water from onshore oil and gas extraction. Environ. Int. 2020, 134, 105280. [CrossRef]

12. Hildenbrand, Z.L.; Carlton, D.D., Jr.; Fontenot, B.E.; Meik, J.M.; Walton, J.L.; Thacker, J.B.; Korlie, S.; Shelor, C.P.; Kadjo, A.F.; Clark, A.; et al. Temporal variation in groundwater quality in the Permian basin of Texas, a region of increasing unconventional oil and gas development. Sci. Total Environ. 2016, 562, 906-913. [CrossRef]

13. Hoelzer, K.; Sumner, A.J.; Karatum, O.; Nelson, R.K.; Drollette, B.D.; O'Connor, M.P.; D’Ambro, E.L.; Getzinger, G.J.; Ferguson, P.L.; Reddy, C.M.; et al. Indications of Transformation Products from Hydraulic Fracturing Additives in Shale-Gas Wastewater. Environ. Sci. Technol. 2016, 50, 8036-8048. [CrossRef]

14. Almaraz, N.; Regnery, J.; Vanzin, G.F.; Riley, S.M.; Ahoor, D.C.; Cath, T.Y. Emergence and fate of volatile iodinated organic compounds during biological treatment of oil and gas produced water. Sci. Total. Environ. 2020, 699, 134202. [CrossRef]

15. Khan, N.A.; Engle, M.; Dungan, B.; Holguin, F.; Xu, P.; Carroll, K.C. Volatile-organic molecular characterization of shale-oil produced water from the Permian Basin. Chemosphere 2016, 148, 126-136. [CrossRef] [PubMed]

16. He, Y.; Flynn, S.L.; Folkerts, E.J.; Zhang, Y.; Ruan, D.; Alessi, D.S.; Martin, J.W.; Goss, G.G. Chemical and toxicological characterizations of hydraulic fracturing flowback and produced water. Water Res. 2017, 114, 78-87. [CrossRef] [PubMed]

17. Luek, J.L.; Schmitt-Kopplin, P.; Mouser, P.J.; Petty, W.T.; Richardson, S.D.; Gonsior, M. Halogenated Organic Compounds Identified in Hydraulic Fracturing Wastewaters Using Ultrahigh Resolution Mass Spectrometry. Environ. Sci. Technol. 2017, 51, 5377-5385. [CrossRef] [PubMed]

18. Luek, J.L.; Harir, M.; Schmitt-Kopplin, P.; Mouser, P.J.; Gonsior, M. Temporal dynamics of halogenated organic compounds in Marcellus Shale flowback. Water Res. 2018, 136, 200-206. [CrossRef]

19. Pals, J.A.; Ang, J.K.; Wagner, E.D.; Plewa, M.J. Biological Mechanism for the Toxicity of Haloacetic Acid Drinking Water Disinfection Byproducts. Environ. Sci. Technol. 2011, 45, 5791-5797. [CrossRef] 
20. States, S.; Cyprych, G.; Stoner, M.; Wydra, F.; Kuchta, J.; Monnell, J.; Casson, L. Marcellus Shale drilling and brominated THMs in Pittsburgh, Pa., drinking water. J. Am. Water Work. Assoc. 2013, 105, E432-E448. [CrossRef]

21. Dong, S.; Nguyen, T.H.; Plewa, M.J. Comparative mammalian cell cytotoxicity of wastewater with elevated bromide and iodide after chlorination, chloramination, or ozonation. J. Environ. Sci. 2017, 58, 296-301. [CrossRef]

22. Plewa, M.J.; Wagner, E.D.; Muellner, E.D.; Hsu, K.; Richardson, S.D. Comparative mammalian cell toxicity of N-DBPs and C-DBPs In Occurrence, Formation, Health Effects and Control of Disinfection by-Products in Drinking Water; Karanfil, T., Ed.; American Chemical Society: Washington, DC, USA, 2008; Volume 995, p. 36.

23. Plewa, M.J.; Muellner, M.G.; Richardson, S.D.; Fasano, F.; Buettner, K.M.; Woo, Y.-T.; McKague, A.B.; Wagner, E.D. Occurrence, Synthesis, and Mammalian Cell Cytotoxicity and Genotoxicity of Haloacetamides: An Emerging Class of Nitrogenous Drinking Water Disinfection Byproducts. Environ. Sci. Technol. 2007, 42, 955-961. [CrossRef]

24. Groundwater Protection Council. Produced Water Report: Regulations, Current Practices and Research Needs; Ground Water Protection Council, Inc.: Oklahoma City, OK, USA, 2019.

25. AQSim-OLI Electrolyte Solutions. White Paper: Selecting an OLI Thermodynamic Framework for Oil and Gas Production; OLI Systems, Inc.: Parsippany, NJ, USA, 2017.

26. Soyluoglu, M.; Ersan, M.S.; Ateia, M.; Karanfil, T. Removal of bromide from natural waters: Bromide-selective vs. conventional ion exchange resins. Chemosphere 2020, 238, 124583. [CrossRef] [PubMed]

27. Zhang, Y.-Q.; Cortes, V.; Phelps, B.; van Ryswyk, H.; Srebotnjak, T. Removal of bromide and bromate from drinking water using granular activated carbon. J. Water Health 2015, 13, 73. [CrossRef] [PubMed]

28. Lin, D.; Liang, H.; Li, G. Factors affecting the removal of bromate and bromide in water by nanofiltration. Environ. Sci. Pollut. Res. 2019, 27, 24639-24649. [CrossRef]

29. Hu, L.; Yu, J.; Luo, H.; Wang, H.; Xu, P.; Zhang, Y. Simultaneous recovery of ammonium, potassium and magnesium from produced water by struvite precipitation. Chem. Eng. J. 2020, 382, 123001. [CrossRef]

30. Sun, M.; Lowry, G.V.; Gregory, K.B. Selective oxidation of bromide in wastewater brines from hydraulic fracturing. Water Res. 2013, 47, 3723-3731. [CrossRef] 